\title{
Does Halting Refugee Resettlement Reduce Crime? Evidence from the US Refugee Ban*
}

\author{
Daniel Masterson ${ }^{\dagger 1,2}$ and Vasil Yasenov ${ }^{2,3}$ \\ ${ }^{1}$ University of California, Santa Barbara \\ ${ }^{2}$ Immigration Policy Lab, Stanford University \\ ${ }^{3}$ IZA - Institute of Labor Economics
}

February 26, 2021

This version to appear in the American Political Science Review

\begin{abstract}
Many countries have reduced refugee admissions in recent years, in part due to fears that refugees and asylum seekers increase crime rates and pose a national security risk. Existing research presents ambiguous expectations about the consequences of refugee resettlement on crime. We leverage a natural experiment in the US, where an Executive Order by the president in January 2017 halted refugee resettlement. This policy change was sudden and significant - it resulted in the lowest number of refugees resettled on US soil since 1977 and a 66\% drop in resettlement from 2016 to 2017. In this letter we find that there is no discernible effect on county-level property or violent crime rates.
\end{abstract}

Keywords: Refugees, immigration, crime

JEL Codes: F22, J15, K42

${ }^{*}$ We thank Alexandra Blackman, Francesco Fasani, Tommaso Frattini, Jens Hainmueller, Jacob Kaplan, Duncan Lawrence, Jonathan Mummolo, Jeff Paller, Giovanni Peri, Matti Sarvimäki, Dan Thompson, Jeremy Weinstein as well as members of the Immigration Policy Lab at Stanford University for helpful suggestions and comments. We have also benefited from seminar participants at the University of San Francisco, UC Davis Economics Alumni Conference and the EARN Workshop for Integration hosted by the University of Copenhagen. Replication materials are available through the APSR Dataverse here.

${ }^{\dagger}$ Corresponding author: Daniel Masterson, University of California, Santa Barbara. Email: masterson@ucsb.edu. 


\section{Introduction}

The number of refugees globally has reached new highs in the last decade and political conflict over the issue has followed. In the US and across Europe, refugees and resettlement have become key campaign issues and common targets of resurgent right-wing parties (Dinas et al., 2019; Dustmann et al., 2019). Earlier political debates about immigration typically centered on its consequences on labor markets, government budgets, and crime (e.g., Hainmueller and Hopkins, 2015; Dancygier and Margalit, 2020). More recently, disagreements over refugee resettlement have focused largely on public safety, with many opponents claiming that refugees put native-born residents at increased risk of crime.

In the US, domestic resettlement agencies administer the placement of refugees, and due to the non-random allocation process we cannot simply infer the effect of refugees on crime by comparing areas that receive many refugees to those that receive few. If we find that high-receiving areas have lower crime rates, this might just reflect the fact that resettlement agencies are reluctant to send refugees to areas with high crime rates. To alleviate selection bias and isolate the causal effect, we require changes in refugee resettlement that are exogenous with respect to local crime trends.

We leverage the large sudden drop in refugee arrivals due to Trump's Executive Order \#13769 of January 2017 (the "refugee ban") as a natural experiment to study whether reducing refugee resettlement impacted crime rates. The ban resulted in much larger reductions in refugee arrivals in counties that had received higher numbers of refugees prior to it. Our difference-in-differences design exploits the fact that this nationwide policy change, based on federal policy considerations rather than local conditions, affected counties very differently in a way that is plausibly uncorrelated with pre-existing crime trends. Multiple tests of observable implications of this assumption support the validity of the research design.

The results show that the reduction in refugee arrivals had a precisely estimated null effect on property and violent crime rates. In other words, crime rates would have been similar had arrivals continued at pre-Executive Order levels. In light of several recent studies from 
Europe suggesting that refugee migration causes a modest rise in crime rates (Gehrsitz and Ungerer, 2017; Dehos, 2017; Lange and Sommerfeld, 2018), our null findings contribute to our understanding of a highly contentious dimension of immigration policy. Our work most directly contributes to the literature on the social and economic effects of immigration (e.g., Borjas, 2017; Peri and Yasenov, 2019), which in turn has implications for understanding the drivers of political attitudes around migration (e.g., Scheve and Slaughter, 2001; Hainmueller and Hopkins, 2015).

\section{Theoretical Expectations about Refugees and Crime}

Existing empirical research has found varied estimates of the relationship between immigration and crime. Although the evidence suggesting immigration increases crime, particularly violent crime, is thin (Ousey and Kubrin, 2018), there is significant heterogeneity in findings across studies depending on the context and research design, and types of immigration and crime (see, e.g., Shihadeh and Barranco, 2010; Berardi and Bucerius, 2014).

Refugees are a particular subset of immigrants and differ from economic migrants in both their observable characteristics and the drivers behind their migration decisions (Dustmann et al., 2017), differences that suggest the need for special consideration of the impact of refugees specifically on crime. Recent studies focusing on refugees in Germany find small increases in crime rates due to the inflow of refugee migrants (Gehrsitz and Ungerer, 2017; Dehos, 2017; Lange and Sommerfeld, 2018). Although the evidence is still too limited and provisional for clear conclusions, it highlights the importance of studying the question elsewhere, especially as broader evidence on the immigration-crime relationship shows that it may differ across countries, such as in the US compared to Europe (see, e.g., Berardi and Bucerius, 2014; Milton et al., 2013). There is a paucity of research on the effects of refugee resettlement on crime in the US. The one exception is a recent study that broadly examines data from 2006 through 2014 and finds no evidence of an effect of refugee resettlement on 
crime or terrorism (Amuedo-Dorantes et al., 2020). We build on their work through a novel estimation strategy, analyzing the Executive Order as a natural experiment associated with a large, sharp, and sudden variation in resettlement around 2017.

Existing theory presents ambiguous expectations about the consequences of refugee resettlement on crime. On the one hand, resettlement could increase crime rates if the refugees are a crime-prone demographic. First, people migrating from places where violence is widespread may have a relatively high propensity to commit violent crimes. Living in environments with extreme hardship, such as urban slums and refugee camps, could have long-term psychosocial impacts, including social disaffection, depression, or post-traumatic stress disorder, and impact the propensity for anti-social behavior. Traumatic experiences, including living through or witnessing violence, poverty, and sexual violence, have been widely demonstrated to be predictive of aggressive and criminal behavior (Ardino, 2012). Looking specifically at refugee resettlement in Switzerland, Couttenier et al. (2019) find evidence that refugees who lived through war as children committed more crimes after resettlement than those who had not experienced war.

Second, even if refugees are not a crime-prone demographic, arriving in a new country could lead people to commit nonviolent crimes due to economic hardship or social alienation. Economic reasons could drive people to turn to illegal market opportunities whether through theft or the drug trade (Ousey and Kubrin, 2009). Simmler et al. (2017) find that refugees in Switzerland were more likely to commit property crime (e.g., shoplifting) than Swiss natives and other immigrant populations, and argue that the difference is driven by psycho-social challenges of arriving in a new country as a refugee.

Another pathway that may link refugee resettlement to higher crime is that natives may commit more crimes targeting refugees as resettlement increases. Today refugee resettlement is a highly salient political issue in many countries, and climates of xenophobia and antiimmigrant sentiment may foster a high risk of anti-refugee violence. Hangartner et al. (2019) show that exposure to refugees in Greece can increase anti-refugee crime and hostility. There 
is also evidence from Germany that higher levels of refugee immigration led to more antirefugee violence (Marbach and Ropers, 2018). Lastly, Müller and Schwarz (2017) show that that right-wing hate speech on social media can incite higher levels of anti-refugee violence.

On the other hand, refugees selected for resettlement may be less likely to commit crimes than natives. Formal resettlement systems, including the US program, explicitly aim to screen out 'high-risk' individuals. Multiple agencies such as the Central Intelligence Agency

and the Department of Homeland Security screen resettlement applicants and run extensive background checks. Successful applicants are often subjected to further screening once they arrive on US soil. These programs typically prioritize applicants based on family reunion or vulnerability-based criteria, including injuries, medical problems, and other forms of hardship. By 'selecting in' family-based and high-vulnerability cases, countries may be indirectly selecting a subpopulation with a low propensity to commit crimes.

Moreover, the structure of refugee resettlement may depress crime rates since many refugees are aiming for permanent residency and citizenship, and a criminal record would undermine this objective. Refugees are more likely to naturalize within six years than nonrefugee immigrants - $45 \%$ compared to $29 \%$ (Mossaad et al., 2018). In the US, resettled refugees can apply for permanent residency and naturalization one and four years after arrival, respectively. Given that a criminal record could lead to an application being denied, refugees face higher costs for crimes than a similar native. In Germany, Lange and Sommerfeld (2018) compare crime propensity across nationalities of origin and find that asylum seekers who have higher ex ante probability of being granted asylum are less likely to commit crimes.

\section{Data}

To test for a link between resettlement and local crime, we use the Federal Bureau of Investigation's (FBI) Offenses Known to Law Enforcement series from the Uniform Crime Reports 
(UCR) database. UCR provides a nationwide statistical effort to collect and report data on crimes brought to the attention of various law enforcement agencies. We focus on a sample of 18,172 local law enforcement agencies which consistently report crime statistics throughout the 2010-2018 period. UCR contains information on reported incidents of violent crime (aggravated assault, rape, murder, and robbery) and property crime (burglary, theft, and motor vehicle theft). Following the crime literature, we convert the reported absolute number of crimes into crime rates per 100,000 population as our main outcome of interest and use a $\log$ transformation as an alternative specification.

We supplement this with refugee resettlement data from the Worldwide Refugee Admissions Processing System (WRAPS) database from the Refugee Processing Center which contains yearly information on refugee arrivals to the US by country of origin and destination city. WRAPS is managed by the Bureau of Population, Refugees, and Migration and serves to provide a standardized management system and accountability to the US refugee resettlement program. ${ }^{1}$ We convert the refugee flow numbers to shares per 100 population as our main explanatory variable of interest, and use logarithmic transformation as a robustness check. Throughout this period, 787 counties in all 50 states received refugee arrivals.

We merge the data sources together and our analysis focuses on the county-year level covering the 2010-2018 time period. ${ }^{2}$ Lastly, we use county-level population estimates from the American Community Survey (ACS) from Manson et al. (2020).

\section{Empirical Strategy}

\section{Design}

Figure 1 illustrates our research design. Panel A shows the large and sudden drop in refugee arrivals following the Executive Order in 2017. We exploit the fact that this nationwide

\footnotetext{
${ }^{1}$ See the Appendix for more information on the US Refugee Admissions Program.

${ }^{2}$ County is the lowest level of geographical aggregation which allows for a consistent merge between the two data sources.
} 
reduction affected counties very differently. As shown in Panel B, the ban resulted in much larger reductions in refugee arrivals in counties that had received larger numbers of refugees prior to the ban. We use two specifications of the difference-in-differences estimator to analyze the effect of reducing refugee resettlement on crime rates. This approach compares changes in crime rates after the Executive Order in counties that received many refugees before the ban to crime rates in counties that received fewer refugees.

The identifying assumption states that in the absence of the policy change, crime in areas with larger drops in resettlement due to the Executive Order would have followed a trajectory (or trend) similar to areas with smaller reductions. See the Appendix for formal tests showing areas with different levels of refugee resettlement were moving along similar crime trends before the ban, supporting our identifying assumption.

\section{First-Differences Model}

The first model we estimate is:

$$
\Delta \text { crime }_{c}^{\text {pre-post }}=\alpha_{1}+\beta_{1} \times \Delta \text { refugees }{ }_{c}^{\text {pre-post }}+\phi_{\text {state }}+\epsilon_{c}
$$

where $c$ denotes county and $s$ indexes states. The outcome variable $\Delta$ crime $e_{c}^{\text {pre-post }}$ measures the $2015 / 16-2017 / 18$ change in a separate crime type per 100,000 people (or in log number of crimes +1$)$. Similarly, the independent variable of interest, $\Delta$ refugees ${ }_{c}^{\text {pre-post }}$ is the corresponding change in refugee arrivals per 100 people (or in log number of refugees +1 ), where $\Delta>0(<0)$ denotes an increase (decrease) in refugee resettlement in county $c$ from 2015/16 to 2017/18. We pool the 2015 and 2016 (2017 and 2018) data together to form an observation for the "pre" ("post") Executive Order period. The term $\phi_{\text {state }}$ controls for state fixed effects allowing for state-specific crime trends during this period. The intercept is $\alpha_{1}$ and $\epsilon_{c}$ is the error term. We cluster the standard errors by state. A positive sign on $\beta_{1}$ indicates that refugee resettlement is associated with an increase in crime rates. In the 
model where both variables are in expressed in rates, $\beta_{1}$ is interpreted as the change in crime rate for each additional refugee arrival per 100 people. Similarly, in the log-log model, it is the percent change in the number of crimes for a one percent increase in refugee arrivals.

\section{Continuous Difference-in-Differences Model}

Second, we move on to a more rigorous model in which we use data from the entire sample period 2010-2018. Specifically, we estimate:

$$
\text { crime }_{c t}=\alpha_{2}+\beta_{2} \times \text { refugees }_{c}^{2016} \times \mathbf{1}(t>2016)+\gamma_{c}+\delta_{t}+X_{c t}+\epsilon_{c t},
$$

where $c$ indexes counties, $t$ denotes year and $\mathbf{1}(t>2016)$ is an indicator for years 2017 and 2018, corresponding to the period after the Executive Order. The outcome is a separate crime type measured in rate per 100,000 population (or the log number of crimes +1 ). The treatment variable refugees ${ }_{c}^{2016}$ is the 2016 refugee arrivals per 100 population (or the $\log$ number of refugees +1 ) and is designed to measure county-level reductions in resettlement due to the Executive Order. We include county fixed effects $\left(\gamma_{c}\right)$ adjusting for permanent county-level characteristics affecting crime rates and refugee arrivals and year fixed effects $\left(\delta_{t}\right)$ accounting for nationwide crime trends. The term $X_{c t}$ captures county-specific linear time trends allowing for idiosyncratic trends across localities. We cluster the standard errors by state. The intercept is $\alpha_{2}$ and $\epsilon_{c t}$ is the error term. Note that compared to the model above, the interpretation of $\beta_{2}$ is switched so that a negative sign would indicate that counties with higher levels of refugee resettlement in 2016 experienced larger drops in crime rates in 2017 and 2018. Thus, a negative sign on $\beta_{2}$ is consistent with the hypothesis that refugee resettlement leads to higher crime rates. 


\section{Results}

Figure 2 provides a graphical summary of the main findings. It plots the relationship between 2015/16-2017/18 changes in refugee arrivals and contemporaneous changes in crime rates along with the local non-parametric regression (LOESS) fit in blue. If refugee resettlement led to higher crime rates, we would observe an upward sloping regression line. Across both types of crimes (left versus right plots) and when measured in rates and logs (top versus bottom plots), we find no discernible relationship between the reduction in refugee arrivals due the the ban and subsequent changes in the local crime rates.

Table 1 presents the regression results using the first-difference model in Equation (1), which is equivalent to fitting a straight line in these scatterplots (with the potential for controlling for state fixed effects). ${ }^{3}$ All coefficients are small in substantive terms and none is statistically significant, indicating an absence of a relationship between resettlement and crime. We discuss the magnitude of effect estimates in the next section.

Table 2 presents the results from the continuous difference-in-differences model in Equation (2). Note again that here a positive coefficient indicates that higher refugee resettlement is associated with lower rates of crime. The table layout is similar to the one above with the exception that in the even-numbered columns we control for county-specific crime trends. All point estimates except for one are positive, and the one negative estimate is not statistically significant. The one statistically significant point estimate (in column 5) is positive, indicating that counties with larger reductions in refugee arrivals experienced larger increases in property crime rates following the ban.

Overall, the results provide little evidence that the reduction in refugee resettlement due to the ban had a discernible impact on crime rates. As with any statistical result, point estimates are (weighted) averages across the full sample, and may mask variation within subgroups. We present a series of robustness checks in the Appendix, such as subsetting to

\footnotetext{
${ }^{3}$ To improve precision, we drop counties with changes in crime rates larger than 1,000 in absolute value which results in excluding 12 counties, on average. Our results remain qualitatively the same but are estimated less precisely in our full sample.
} 
urban counties, using all 3,112 US counties, varying the specification of the statistical model (such as weighting and dropping outliers), adjusting for demographic control variables and spatially lagged crime rates, and testing for impacts on internal migration, crime-reporting behavior, and a one-year crime lead. Evidence consistently provides no clear indication of a relationship between refugee resettlement and crime.

\section{Discussion}

\section{Effect Sizes and Estimates' Precision}

To interpret the estimated effect sizes, we first need to consider whether the US program is sufficiently large to provide evidence of a meaningful null relationship. Until 2016, it was the world's largest, resettling more refugees every year than the rest of the world combined (Connor and Krogstad, 2018). The 2016/17 reduction in resettlement was, therefore, approaching the largest possible cut we could observe empirically. In other words, given the historical magnitude of refugee resettlement programs around the world, this case provides a critical test of the relationship between refugees and crime.

Next, we explore how precisely estimated the null effects we report are, thereby testing whether the study has sufficient power to detect reasonably small effects of the intervention. We begin by presenting the expected percentage change in crime for a one percent increase in resettlement as predicted by our statistical models (corresponding to models in oddnumbered columns in Tables 1 and 2). We then do the same for a one standard deviation increase in resettlement, and compare those changes to the median crime rates. Results are presented in Table A19 in the Appendix.

Based on the results from the continuous difference-in-differences model, Panel B, columns 3 and 4 , show that the estimated change in crime rates for a one percent increase in pre-ban refugee resettlement is $0.014 \%[-0.021 \%, 0.006 \%]$ for property crime, and $0.001 \%[-0.011 \%$, $0.009 \%$ ] for violent crime. In the rates models (Panel B, columns 1 and 2), the predicted 
change in property and violent crime rates for a one standard deviation shift in refugee resettlement are $14.597[-15.544,44.738]$ and $-3.696[-12.000,4.608]$ respectively. These point estimates are very small in comparison to median county-level crime rates: 2317.855 (property crime) and 254.387 (violent crime). The magnitudes of results in the first-difference models are similar (also presented in Panel B). Overall, the estimated effects are small in magnitude and precisely estimated in levels as well as logs, supporting an interpretation of the results as meaningful null findings.

\section{Internal Migration Following Resettlement}

How long do refugees resettled to one area reside there before moving elsewhere? If refugees move quickly from their initial destination to other locations, we would likely not expect to find any relationship between initial location of resettlement and crime. We use data from the US Office of Refugee Resettlement's (ORR) annual reports to calculate the number of refugees who made inter-state moves in 2013 and 2014 (U.S. Department of Health and Human Services: Office of Refugee Resettlement, 2014, 2015). Approximately 3.9\% of refugees who had arrived in the past four years (after which they can apply for naturalization) moved per year. ${ }^{4,5}$ This shows that refugees do not relocate at high rates, mitigating the concern that the null result is driven by high secondary migration of resettled refugees. The data currently available from ORR provides estimates at the state level rather than county level, and intrastate mobility among this population could be significantly higher than interstate moves. ${ }^{6}$

\footnotetext{
${ }^{4}$ We discuss our analysis of ORR data in the Appendix.

${ }^{5}$ Using a longer time window and earlier study period, Mossaad et al. (2020) estimate that from 2000$201417 \%$ of refugees moved between states within two years of their arrival. Not only is the time window wider but also inter-state mobility has trended downward in the US since 2000 (Molloy et al., 2011).

${ }^{6}$ Based on tests shown in the Appendix, we find no evidence for the possibility that the Executive Order affected the migration choices of natives and other residents.
} 


\section{Conclusion}

In this letter we estimate the effect of a large and significant cut to the US refugee resettlement program, and find that there is no discernible short-term effect on county-level property or violent crime rates. There are at least three factors that likely contribute to this result. The first is the selection process of refugees and extensive multi-agency background checks. Candidates for resettlement go through several interviews and background checks before being admitted and are often subjected to further screening once they arrive on US soil. In addition, refugees are typically selected on vulnerability-based criteria, which prioritize people with injuries and other forms of hardship. Given this selection process, it appears likely that admitted refugees are, on average, no more prone to engage in criminal activity than the general native population.

The second factor involves the scale of refugee resettlement. Historically, until the Executive Order, the US resettled more refugees each year than the rest of the world combined. Hence, this policy reversal represents about as large of a change as realistically possible. Nevertheless, its size is small relative to the population and hence resettlement is unable to ultimately change local crime rates. A much larger resettlement program, which more profoundly altered the demographics of the US population, might have distinct equilibrium effects on the economy and society than what our study identifies.

Third, the demographic composition of people resettled to the US differs from that of asylum seekers in Europe. The recent group of asylum seekers in Germany consists predominantly of young men, the demographic group that is considered at highest risk to commit crimes (Freeman, 1999). For example, in 2016, 34\% of asylum seekers in Germany were men between the ages of 18 and 35 (Eurostat, n.d.). In contrast, our calculations show approximately $14 \%$ of the refugees resettled to the US in 2016 were men within a similar age range.

After decades of increasingly liberal immigration policy in much of the Western world, the region appears to now be entering a period of hardening national boundaries. Under- 
standing the impacts of such immigration policy reversals will be critical for future research in the political economy of migration. Here we show that restricting refugee resettlement to the US is not an effective policy tool for reducing crime. This finding contributes to our understanding of a central element of political conflict and public opinion related to immigration policy. 


\section{References}

Amuedo-Dorantes, Catalina, Cynthia Bansak, and Susan Pozo, "Refugee Admissions and Public Safety: Are Refugee Settlement Areas More Prone to Crime?," International Migration Review, 2020.

Ardino, Vittoria, "Offending behaviour: The role of trauma and PTSD," European Journal of Psychotraumatology, 2012, 3 (1).

Berardi, Luca and Sandra Bucerius, "Immigrants and their children: Evidence on generational differences in crime," The Oxford handbook of ethnicity, crime, and immigration, 2014, pp. 551-583.

Borjas, George J, "The wage impact of the Marielitos: A reappraisal," ILR Review, 2017, 70 (5), 1077-1110.

Connor, Phillip and Jens Manuel Krogstad, "For the first time, U.S. resettles fewer refugees than the rest of the world," Pew Research Center, 2018.

Couttenier, Mathieu, Veronica Petrencu, Dominic Rohner, and Mathias Thoenig, "The Violent Legacy of Conflict: Evidence on Asylum Seekers, Crime, and Public Policy in Switzerland," American Economic Review, 2019, 109 (12), 4378-4425.

Dancygier, Rafaela and Yotam Margalit, "The evolution of the immigration debate: Evidence from a new dataset of party positions over the last half-century," Comparative Political Studies, 2020, 53 (5), 734-774.

Dehos, Fabian T, "The refugee wave to Germany and its impact on crime," Technical Report, Ruhr Economic Papers 2017.

Dinas, Elias, Konstantinos Matakos, Dimitrios Xefteris, and Dominik Hangartner, "Waking Up the Golden Dawn: Does Exposure to the Refugee Crisis Increase Support for Extreme-Right Parties?," Political Analysis, 2019, pp. 1-11.

Dustmann, Christian, Francesco Fasani, Tommaso Frattini, Luigi Minale, and Uta Schönberg, "On the economics and politics of refugee migration," Economic policy, 2017, 32 (91), 497-550.

_, Kristine Vasiljeva, and Anna Piil Damm, "Refugee migration and electoral outcomes," The Review of Economic Studies, 2019, 86 (5), 2035-2091.

Eurostat, "Asylum Seeker Data. http://appsso.eurostat.ec.europa.eu/nui/submitViewTableAction.do. Accessed December 16, 2018."

Freeman, Richard B, "The economics of crime," Handbook of labor economics, 1999, 3, 3529-3571.

Gehrsitz, Markus and Martin Ungerer, "Jobs, Crime, and Votes : A Short-run Evaluation of the Refugee Crisis in Germany.," 2017, (10494). 
Hainmueller, Jens and Daniel J Hopkins, "The hidden American immigration consensus: A conjoint analysis of attitudes toward immigrants," American Journal of Political Science, 2015, 59 (3), 529-548.

Hangartner, Dominik, Elias Dinas, Moritz Marbach, Konstantinos Matakos, and Dimitrios Xefteris, "Does exposure to the refugee crisis make natives more hostile?," American Political Science Review, 2019, 113 (2), 442-455.

Lange, Martin and Katrin Sommerfeld, "Causal Effects of Immigration on Crime: Quasi-Experimental Evidence from a Large Inflow of Asylum Seekers.," Working paper, 2018.

Manson, Steven, Jonathan Schroeder, David Van Riper, Tracy Kugler, and Steven Ruggles, "IPUMS National Historical Geographic Information System: Version 15.0 [dataset]," 2020.

Marbach, Moritz and Guido Ropers, "Not in My Backyard: Do Increases in Immigration Cause Political Violence?," IPL Working paper, 2018, 18-02.

Milton, Daniel, Megan Spencer, and Michael Findley, "Radicalism of the Hopeless: Refugee Flows and Transnational Terrorism," International Interactions, 2013, 39 (5), 621-645.

Molloy, Raven, Christopher L Smith, and Abigail Wozniak, "Internal migration in the United States," Journal of Economic perspectives, 2011, 25 (3), 173-196.

Mossaad, Nadwa, Jeremy Ferwerda, Duncan Lawrence, Jeremy M Weinstein, and Jens Hainmueller, "Determinants of refugee naturalization in the United States," Proceedings of the National Academy of Sciences, 2018, 115 (37), 9175-9180.

_ , _ , , Jeremy Weinstein, and Jens Hainmueller, "In search of opportunity and community: Internal migration of refugees in the United States," Science advances, 2020, 6 (32), eabb0295.

Müller, Karsten and Carlo Schwarz, "Fanning the Flames of Hate: Social Media and Hate Crime," Working paper, 2017.

Ousey, Graham C and Charis E Kubrin, "Exploring the connection between immigration and violent crime rates in US cities, 1980-2000," Social problems, 2009, 56 (3), $447-473$.

_ and _, "Immigration and crime: Assessing a contentious issue," Annual Review of Criminology, 2018, 1, 63-84.

Peri, Giovanni and Vasil Yasenov, "The labor market effects of a refugee wave synthetic control method meets the mariel boatlift," Journal of Human Resources, 2019, 54 (2), 267-309. 
Scheve, Kenneth F. and Matthew J. Slaughter, "Labor Market Competition and Individual Preferences Over Immigration Policy," Review of Economics and Statistics, 2001, 83 (1), 133-145.

Shihadeh, Edward S and Raymond E Barranco, "Latino employment and Black violence: The unintended consequence of US immigration policy," Social Forces, 2010, 88 (3), 1393-1420.

Simmler, Monika, Isabelle Plassard, Noëmie Schär, and Maximilian Schuster, "Understanding Pathways to Crime: Can Anomie Theory Explain Higher Crime Rates Among Refugees?-Current Findings from a Swiss Survey," European journal on criminal policy and research, 2017, 23 (4), 539-558.

U.S. Department of Health and Human Services: Office of Refugee Resettlement, "Statistical Abstract for Refugee Resettlement Stakeholders: July 2014," 2014.

_ , "ORR Indicators for Refugee Resettlement Stakeholders: June 2015," 2015. 
Figure 1: Refugee Arrivals in the US and Research Design, 2002-2018
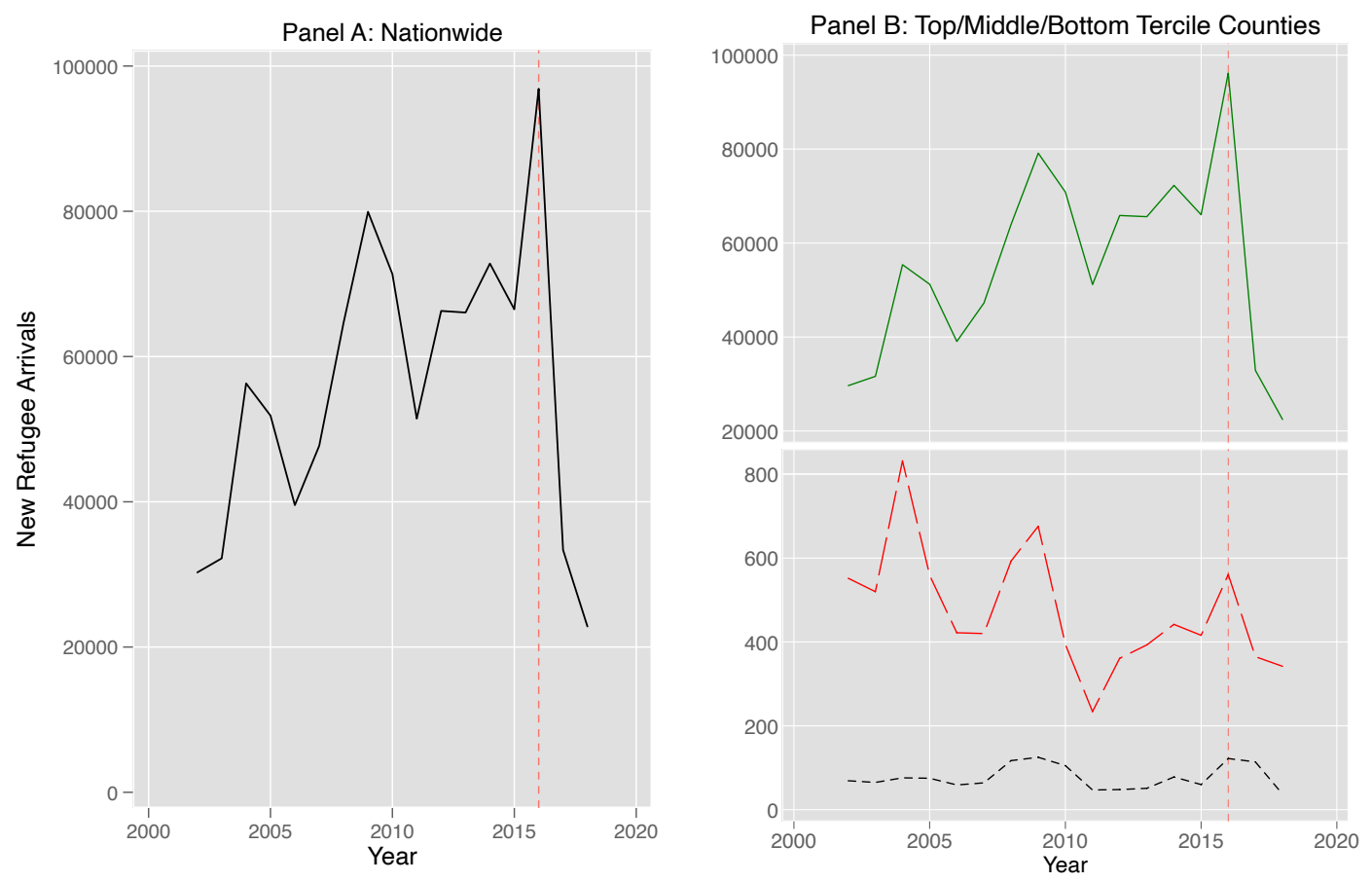

Notes: Panel A shows that refugee arrivals dropped nationwide in early 2017 due to the Executive Order. Panel B visualizes the reduction in arrivals was much larger in counties that received the most refugees prior to the ban. Green (solid), red (long dashed), and black (short dashed) lines indicate average number of arrivals for counties in the top, middle, and bottom tercile in terms of arrivals between 2002 and 2016 . 
Figure 2: The Effect of the Executive Order on Local Crime Rates
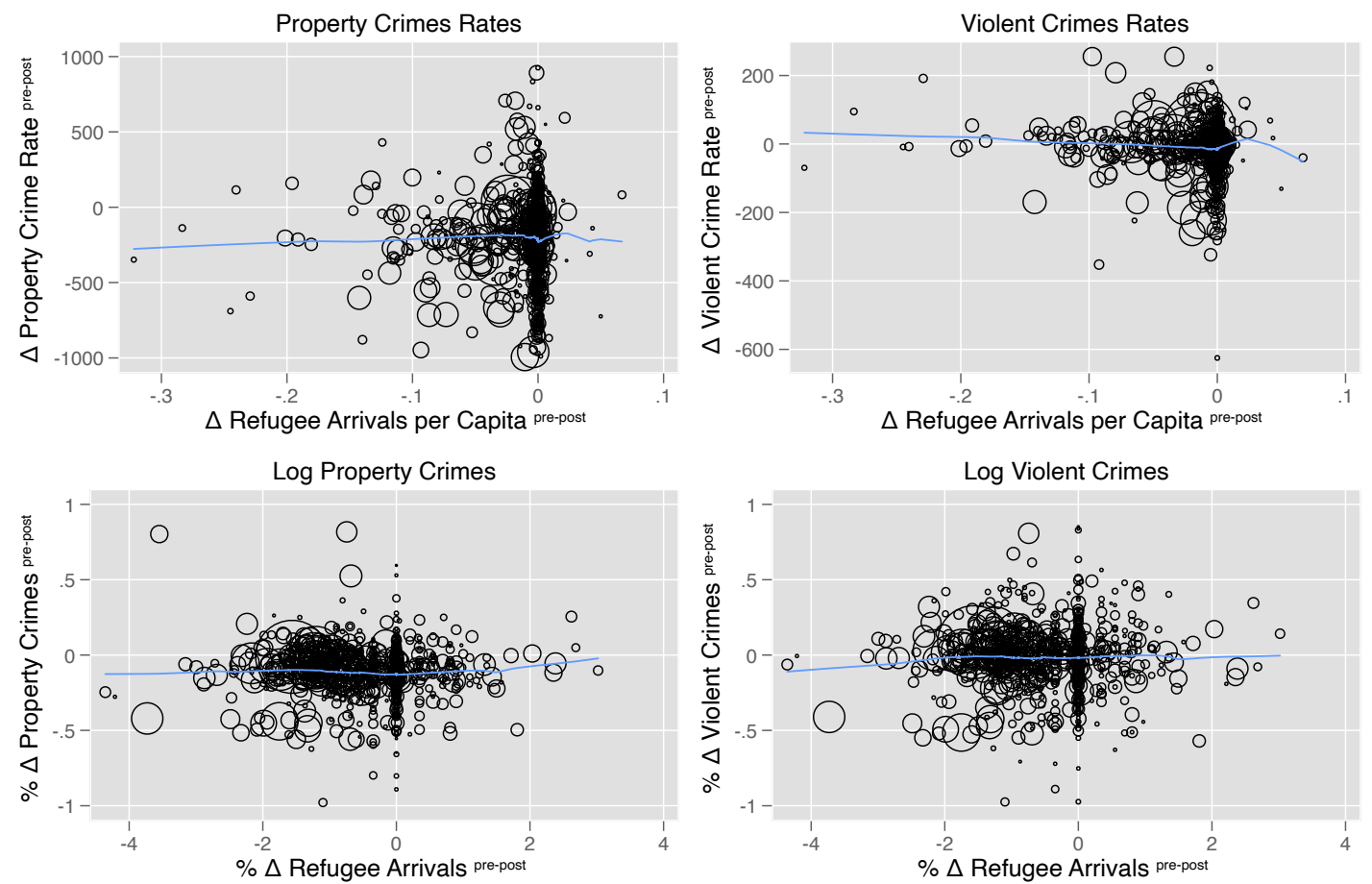

Notes: Crime trends and drop in refugee arrivals before (2015/2016) and after (2017/2018) the Executive Order for property (left panels) and violent (right panels) crimes. The top (bottom) two panels show variables measured in rates (logs). Each circle is a single county and its size is proportional to the 2016 population. LOESS fits are shown in blue lines. 


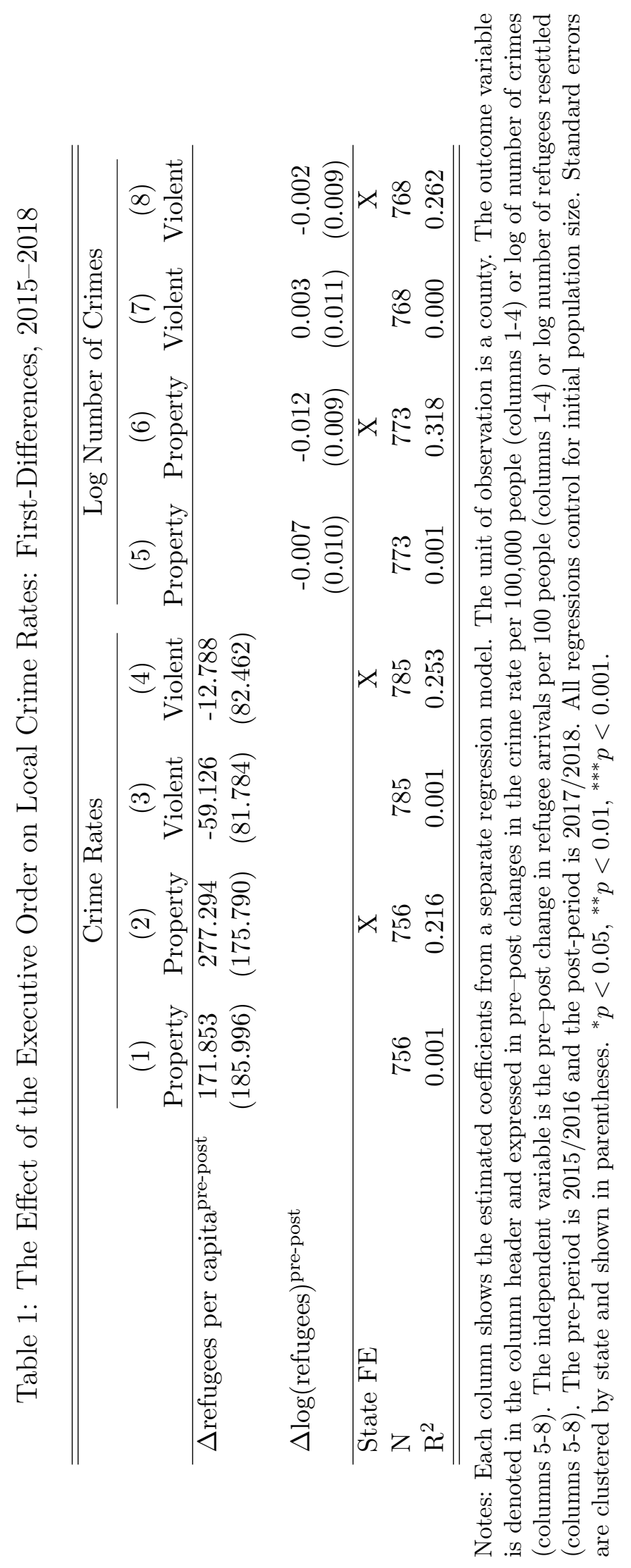




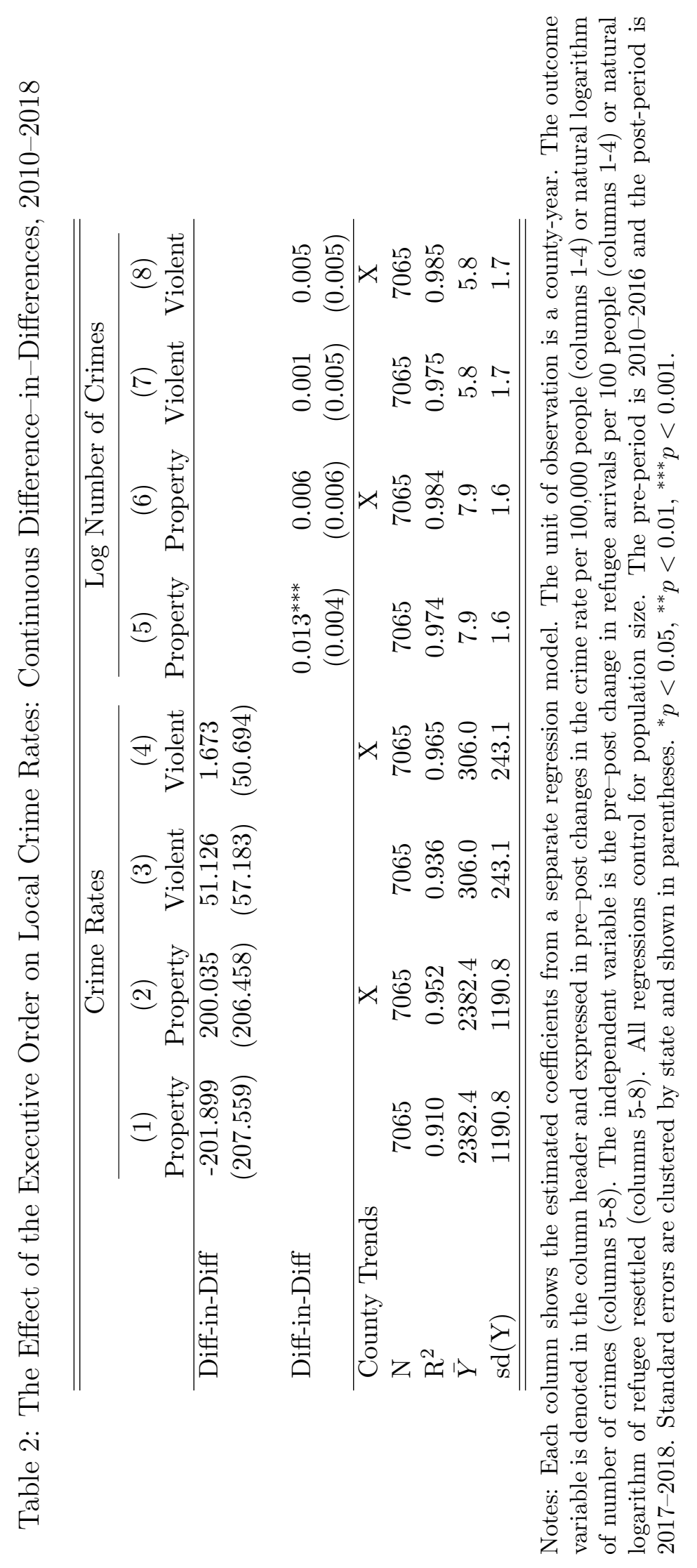




\section{Appendix}

\subsection{The US Refugee Admission Program}

Each year the President of the US and the Congress discuss the worldwide refugee situation and determine the numerical ceiling for refugee admissions. These admissions are then handled and processed by USRAP. USRAP is a collaborative effort between government agencies and nonprofit organizations to identify, admit, and resettle refugees to the US. The program is not hosted by any one particular department of the federal government but, rather, it is spread between various agencies. First, the US Citizenship and Immigration Services (USCIS), within the Department of Homeland Security, is responsible for refugee applications, admissions, and related legal issues. In parallel, the Bureau of Population, Refugees, and Migration, within the Department of State, runs USRAP's operations abroad and plays more of a humanitarian role. For instance, it collaborates with nonprofits on the ground to provide services and aid to refugees. Lastly, the Office of Refugee Resettlement (ORR), within the Department of Health and Human Services, works with admitted refugees to maximize their potential in the US, assisting new refugees with adapting to living and working in their new home.

For a refugee to be considered for admission by USRAP they have to first have been referred by UNHCR, a US embassy abroad, or a designated nonprofit organization. They need to fit the definition of a refugee as described in section 101(a)(42) of the Immigration and Nationality Act. The main condition is that they are unable to return to their country of origin because of a well-founded fear of persecution stemming from their race, religion, political affiliation or membership in any other social group. Once they are deemed eligible and referred to USRAP, a lengthy admission process ensues. It may involve multiple interviews, background checks, and health exams with numerous government agencies including the Department of Homeland Security. Cases based on special humanitarian concern (largely based on nationality) or family reunification are given higher priority. The length of time it takes to complete this screening varies from case to case but sometimes takes multiple years.

Refugees admitted to the US are assigned to one of nine domestic resettlement agencies (e.g., International Rescue Committee, Lutheran Immigration and Refugee Services, US Conference of Catholic Bishops). The agency then chooses the destination where the refugee will be resettled with the goal of maximizing the probability of successful economic and social integration. Factors affecting this choice may include the presence of family members, the size of the local co-ethnic group or proximity to a major health center. The ORR then works with local agencies to provide the newly-admitted refugees with services including cultural orientation, language instruction, and job training.

Note that refugees are sometimes confused with asylum-seekers. Strictly speaking, the latter constitute a group of people who have fled their home country but whose claims for refugee status have not yet been verified. In the US these two groups are strictly distinct as asylum-seekers make it to the US prior to filing for asylum while refugees file for resettlement from overseas. Throughout this letter we focus on refugees and do not analyze data on asylum-seekers.

\subsection{Descriptive Statistics}

Table A1 shows summary statistics for the main variables of interest in our analysis. The data is at the county-year level and the time period is 2010-2018, resulting in 7,065 observations. All crime variables are right-skewed. The mean (median) property crime rate per 100,000 population was $2,385.21(2,213.95)$ per county per year. The mean (median) violent crime rate per 100,000 
population was $1,183.2(1,065.68)$ per county per year. Because we use a logarithmic transformation as a robustness check, we present summary statistics for these variables as well. The bottom rows of Table A1 show summary statistics of our refugee arrival variables. Similar to the crime data, these variables are also right-skewed. The average county received 77.46 (2) refugees per year (per 100 people per year).

Figure A1 shows a map of cumulative refugee arrivals to the US in the time period 2002-2016 for each county. During the time period 787 counties, located in all 50 states, received some refugees. Darker shades of red denote higher refugee arrival levels and white denotes counties that received no refugees in our study period. This figure illustrates the non-random allocation of refugees to localities. In particular, refugees are more likely to be resettled in places near major urban centers such as parts of California, Washington, Florida and the Northeast.

Next, the left panel in Figure A2 shows the top 10 refugee origin countries and the right panel displays the top ten receiving states. All numbers reflect cumulative values for the time period 2002-2016. The three largest sending countries are Burma $(166,115)$, Iraq $(140,468)$ and Somalia $(100,850)$, and the three largest receiving states were California $(102,444)$, Texas $(81,697)$ and New York $(53,737)$. 
Figure A1: Cumulative Refugee Arrivals in the US by County, 2002-2016

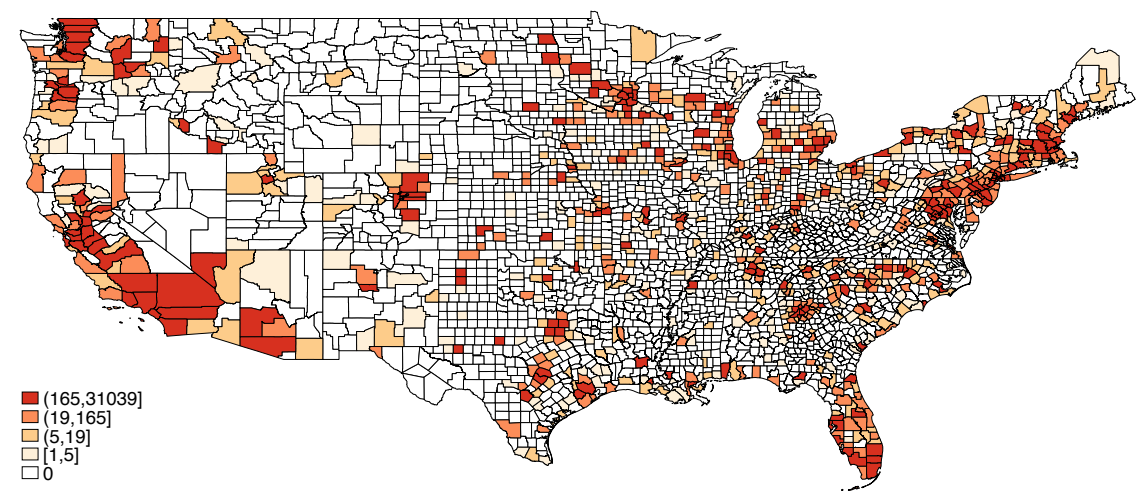

Notes: Cumulative number refugee arrivals in the US for the period prior to the Executive Order, 20022016. Each polygon is a separate county. Darker shades of red correspond to higher number of refugee resettled.

Figure A2: Origins and Destinations for Refugee Arrivals in the US, 2002-2016
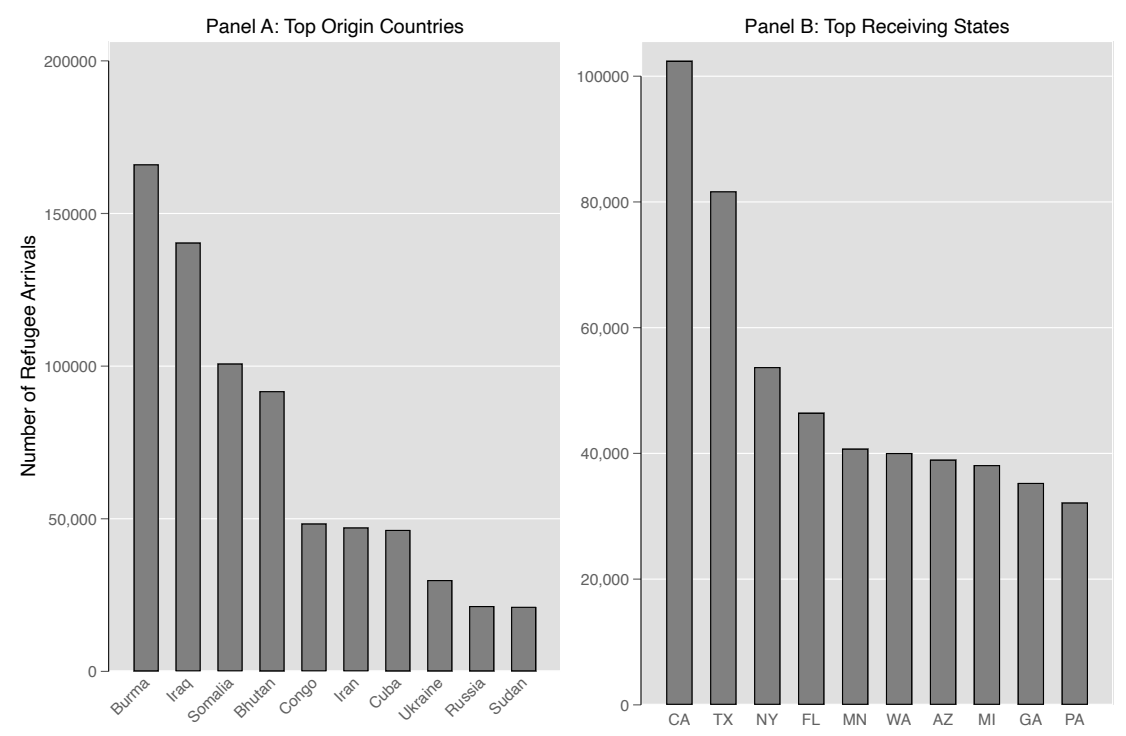

Notes: Panel A shows the top ten refugee sending countries and Panel B presents the top ten receiving states. All numbers reflect aggregate arrival values in the period prior to the Executive Order, 2002-2016. 
Table A1: Descriptive Statistics

\begin{tabular}{|c|c|c|c|c|c|c|}
\hline & Mean & Median & $\mathrm{SD}$ & Min & Max & Observations \\
\hline & \multicolumn{6}{|c|}{ Crime Variables } \\
\hline Property crimes rate & 2382.41 & 2211.59 & 1190.76 & 0 & 9657.12 & 7065 \\
\hline Violent crimes rate & 306.04 & 252.54 & 243.08 & 0 & 3323.85 & 7065 \\
\hline Log property crimes & 7.95 & 8.04 & 1.61 & 0 & 12.44 & 7065 \\
\hline \multirow[t]{2}{*}{ Log violent crimes } & 5.78 & 5.77 & 1.73 & 0 & 10.98 & 7065 \\
\hline & \multicolumn{6}{|c|}{ Refugee Resettlement Variables } \\
\hline Refugee arrivals & 77.46 & 0.00 & 252.93 & 0 & 3474.00 & 7065 \\
\hline Refugee arrivals per 100 people & 0.02 & 0.00 & 0.07 & 0 & 1.78 & 7065 \\
\hline Log refugee arrivals & 1.61 & 0.00 & 2.14 & 0 & 8.15 & 7065 \\
\hline Population (in 100,000s) & 3.09 & 1.42 & 5.84 & 0 & 101.06 & 7065 \\
\hline Observations & 7065 & & & & & \\
\hline
\end{tabular}

Notes: Crime rates are expressed in absolute number of crimes per 100,000 people. The unit of observation is a county and the time period is 2010-2018. Crime data comes from 18,172 local law enforcement units which consistently report data for the entire period without missing entries. 


\subsection{Pre-trends}

To test for violation of the identifying parallel trends assumption, we correlate the 2010-2016 county-level crime trends with the 2015/16-2017/18 drop in refugee arrivals. This test assesses whether crime trends predating the Executive Order are associated with the drop in arrivals due to the refugee ban. Given that the ban was based on national consideration and not on local conditions, we do not expect the two would be correlated. We cluster standard errors by state.

The results are shown in Table A2 and Figures A3 and A4. We find no meaningful relationship between crime pre-trends and the observed 2015/16-2017/18 change in refugee resettlement. Figure A3 presents the results for crime and resettlement measured in rates (top) and logs (bottom) with scatter plots of pre-existing crime trends and drop in resettlement due to the ban . Figure A4 presents crime trends by high/low/medium refugee receiving counties, to search for visual evidence of parallel time crime trends across refugee resettlement terciles. Figure A5 uses an eventstudy approach to explore for possible violations of parallel pre-trends, comparing the year-to-year relationship between refugee resettlement and crime rates, relative to 2016 .

If anything, two of the regression coefficients in the log-log specification in Table A2 (Columns 6 and 8) are negative and statistically significant indicating that counties that lost more refugees may have been on declining crime trends. If true, this would bias our results in the direction of finding that refugee resettlement increases crimes. Nevertheless, this result is not observed in the other six columns of the table or in any of the plots in Figures A3 and A4.

All in all, we conclude that places with differential reductions in resettlement due to the refugee ban were not on different crime trend trajectories before the policy reversal. Consequently, it is

reasonable to assume that these counties would have continued on such parallel crime trends had the ban not occurred and that our research design is valid. 
Figure A3: Pre-existing Crime Trends and Drop in Refugee Arrivals
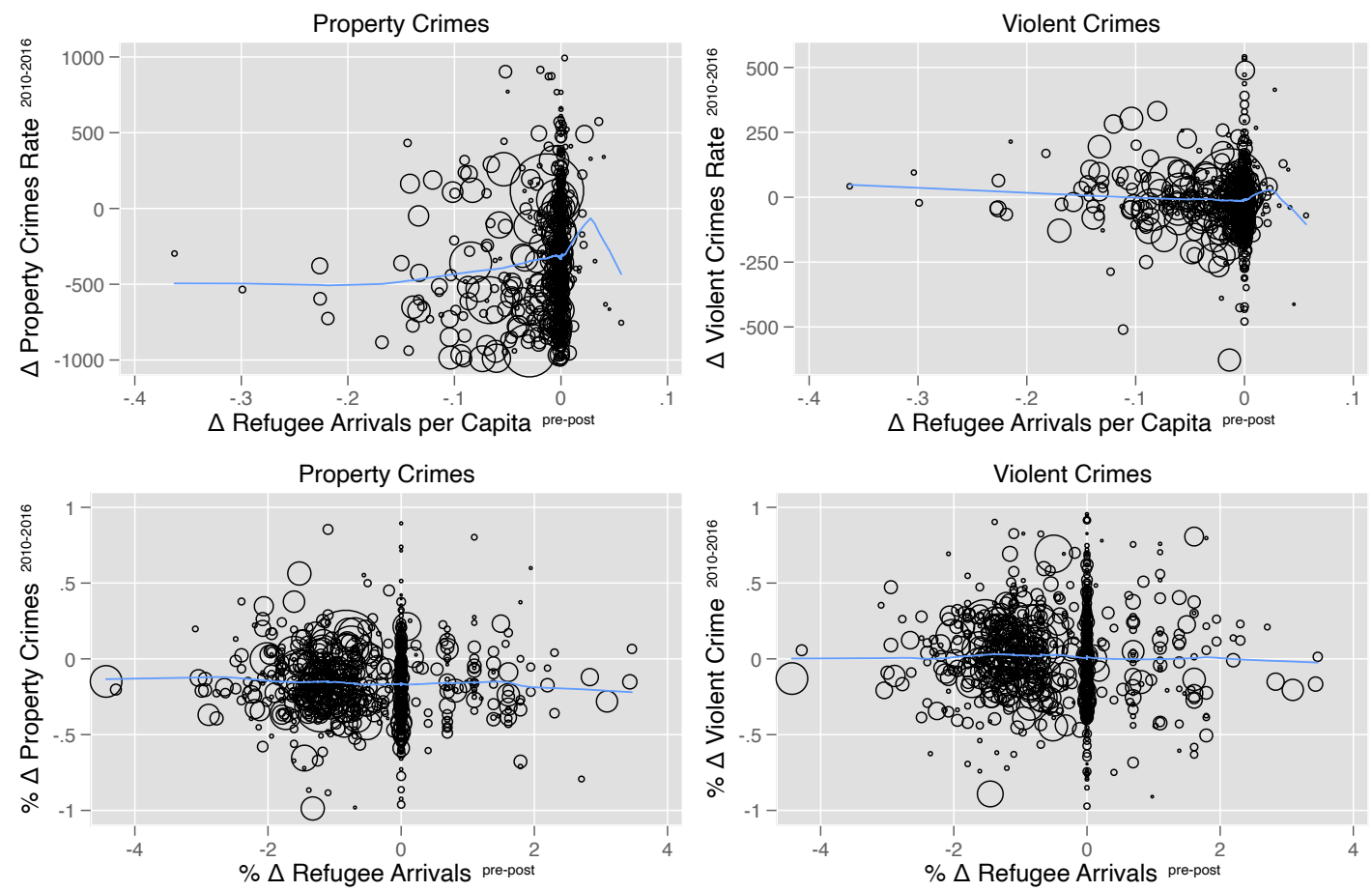

Notes: The top two panels show crime trends between 2010 and 2016 and drop in refugee arrivals due to the Executive Order for property (left) and violent (right) crimes. Local non-parametric regression (LOESS) fits are shown in blue lines. Each circle is a single county and its size is proportional to the 2016 population. The data in the top (bottom) figures are expressed in rates (logarithm). Positive (negative) values in the horizontal axes denote an increase (decrease) in refugee resettlement from 2015/16 to $2017 / 18$. 
Figure A4: Pre-existing Crime Trends and Drop in Refugee Arrivals: Robustness Check 1
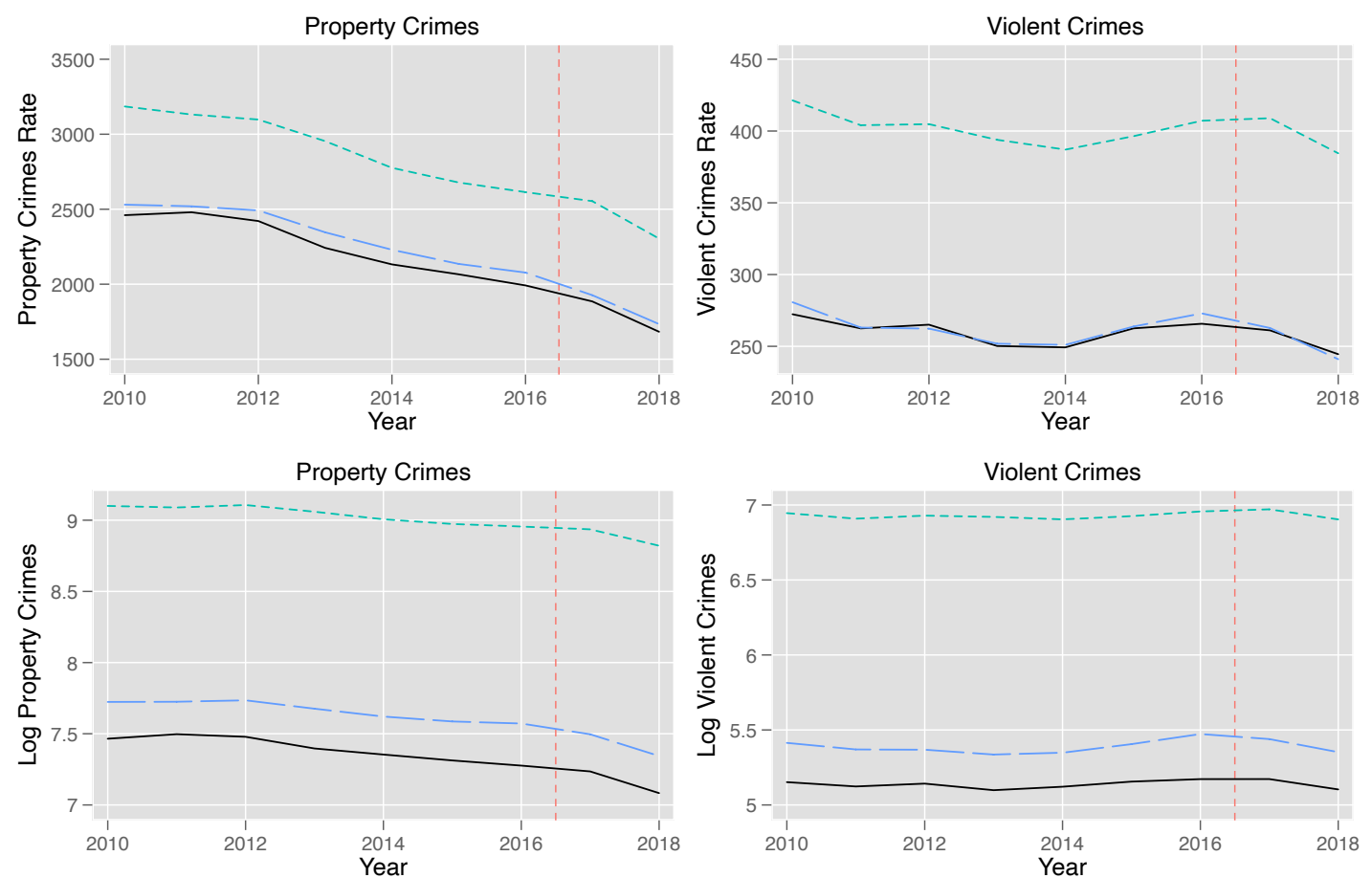

Notes: Crime trends by top/middle/bottom tercile refugee receiving counties for property (left) and violent (right) crimes. The data in the top (bottom) figures are expressed in rates (logarithm). 
Figure A5: Pre-existing Crime Trends and Drop in Refugee Arrivals: Robustness Check 2
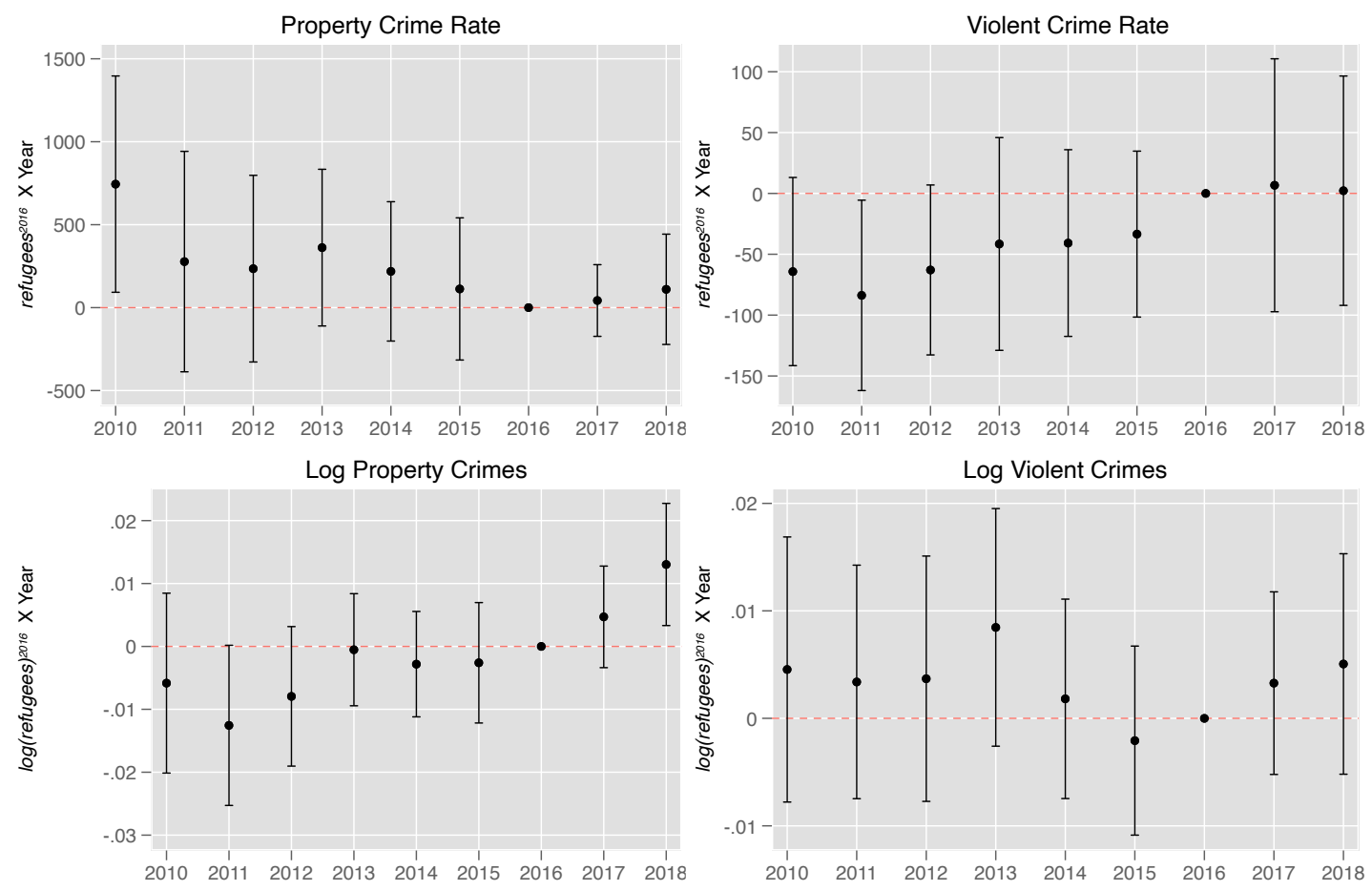

Notes: Coefficients of interactions of exposure to the ban (number of refugees in 2016 per 100 people) and year dummies for property (left) and violent (right) crimes. Year 2016 is omitted and serves as the reference point. The regression model is otherwise identical to that shown in Table 2. The data in the top (bottom) figures are expressed in rates (logarithm). Vertical lines correspond to $95 \%$ confidence intervals. 


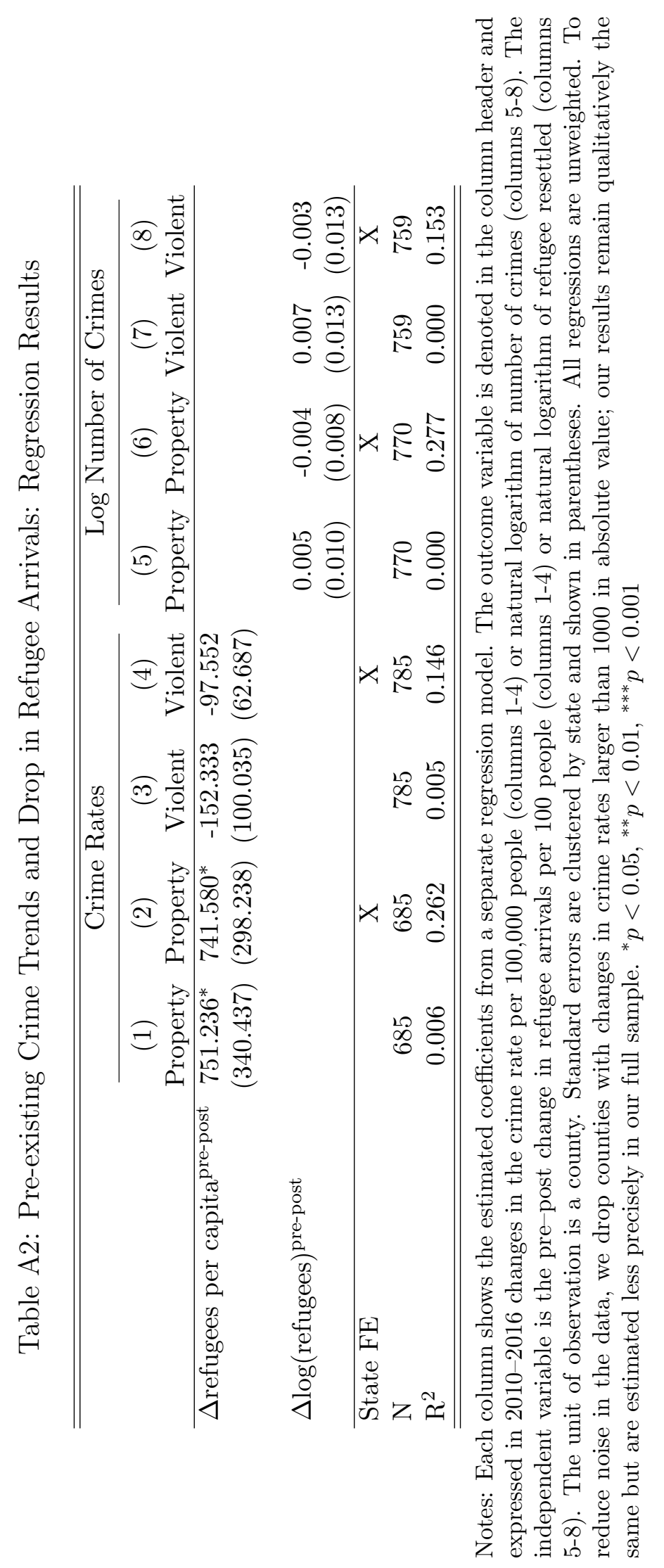




\section{Identifying Assumptions in a Difference-in-differences Design}

Here we provide a critical discussion of the identifying assumptions in a difference-in-differences research design (see, e.g., Lechner, 2011).

\section{SUTVA, no general equilibrium effects or spillover}

Previous studies of crime have identified the possibility that policing that reduces crime in targeted communities may push perpetrators into neighboring areas that did not experience increases in policing (Blattman et al. 2017). In our context, we might be concerned that if refugees increase (decrease) crime upon arriving in resettlement counties, they could have a spillover effect on other counties that leads to a similar increase (decrease) in crime there. Such spillover effects could mean that refugee resettlement does in fact increase (decrease) crime rates, but we would fail to detect that change because we difference out the concomitant spillover effects onto comparison counties.

Our main analysis includes all counties that received at least one refugee during the data period (2010-2018) totaling 787 counties. We also run analysis using all 3,112 US counties. The results are qualitatively identical for the regressions with 787 counties and for all counties, suggesting that spillover effects likely are not playing a crucial role.

We also run the test presented in Bianchi et al. (2012) for spatial spillovers, re-running our regression with all counties, but this time adjusting for spatially lagged crime rates. As in Bianchi et al. (2012) this denotes calculating for each county a weighted average of crime rates in neighboring counties, with weights defined by the distance between county centroid. Results from this regression are presented in Table A5. Results are qualitatively identical to our main results, providing further evidence that spatial spillovers do not play an important role for interpreting our results.

\section{Exogeneity of conditioning variables}

Treatment should not affect conditioning variables. The variables we include, time and county indicators, and a linear time trend that is effectively an interaction of time trends and county indicators, are exogenous by construction.

\section{No effect of treatment on the treated before treatment occurs [treatment had no effect on the pre-treatment population]}

The treatment in our research design is a cut to refugee resettlement. Our research design would be undermined if the policy impacted outcomes in previous time periods, such as if some individuals, institutions, or markets anticipated the policy and reacted before the policy was implemented. So, did Executive Order 13769 affect crime rates before it was announced in January 2017? On January 27, 2017, President Trump signed the Executive Order, 80 days after he had won the US presidential election on November 8, 2016. Donald Trump did not win the presidential election until nearly the end of our 2010-2016 pre-treatment period. Even after that point although more restrictive immigration policies may have been anticipated after the election, during the final two months of 2016, the speed and scale of the order were a shock when it was announced in January. It is unlikely that any anticipation of the policy would have changed how counties or individuals acted before the ban went into effect due to anticipation of this policy in any way sufficient to change crime rates for our pre-period of 2010-2016.

\section{Parallel trends}

We provide extensive tests of the parallel trends assumption in Appendix Section 1.3. The parallel trends assumption is ultimately about counterfactual and unobservable behavior of after treatment if units had received different levels of treatment, and therefore cannot be directly tested. 
That being said, results from pre-treatment periods support the credibility of the assumption. Our study has the benefit of including data from seven pre-treatment years (2010-2016) increasing our ability to detect differential pre-treatment time trends if they existed.

\section{Common support}

Although the preceding assumptions are all formulated in terms of unobservable random variables and are not testable, we can in fact test the fifth assumption. With sufficient density in these distributions across treatment levels, we can demonstrate sufficient common support to avoid effect estimates being fragile and model-dependent. We can analyze this by dividing observations into bins with respect to treatment and covariates and checking common support. Reassuringly, the results presented below provide strong evidence of common support with respect to our covariates.

The only covariates in our main specification are state and year fixed effects. By design, year fixed effects are balanced between treatment and control counties. However, this is not necessarily true for the state fixed effects.

Since our treatment variable is continuous, we separate all counties in our sample into two bins depending on the value for our treatment variable for the resettlement rate specification (number of refugees in 2016 per 100 capita) - above median ("treatment") and below median ("control"). We then check whether each state has counties in both bins (i.e., common support). Reassuringly, we find that this is true for all states except for Delaware and Hawaii (only in control) and Nevada and Wyoming (only in treatment).

We then re-run our main regression specification without these four states in the sample. The results are presented in Table A11. Reassuringly, the results align with the results in our main model. If anything, the one statistically significant coefficient (column 5) is consistent with refugees decreasing crime rates. 


\subsection{Robustness Checks}

\subsubsection{Adding Demographic Controls}

- It is possible that other population changes may have occurred during the study time frame correlated with crime and refugee resettlement.

- Therefore we replicate Tables 1 and 2 and add the following control variables: (log) population, share Black, share White, share Hispanic, share high school dropouts, share high school graduates, unemployment rate, share out of labor force, share males ages 15-34.

Table A3: The Effect of the Executive Order on Local Crime Rates: First Differences, Adding Controls

\begin{tabular}{|c|c|c|c|c|c|c|c|c|}
\hline & \multicolumn{4}{|c|}{ Crime Rates } & \multicolumn{4}{|c|}{ Log Number of Crimes } \\
\hline & $(1)$ & $(2)$ & $(3)$ & $(4)$ & $(5)$ & (6) & $(7)$ & $(8)$ \\
\hline & Property & Property & Violent & Violent & Property & Property & Violent & Violent \\
\hline$\Delta$ refugees per capita ${ }^{\text {pre-post }}$ & $\begin{array}{c}314.863 \\
(186.002)\end{array}$ & $\begin{array}{c}347.484 \\
(190.039)\end{array}$ & $\begin{array}{c}-30.173 \\
(78.790)\end{array}$ & $\begin{array}{l}-10.668 \\
(69.120)\end{array}$ & & & & \\
\hline$\Delta \log (\text { refugees })^{\text {pre-post }}$ & & & & & $\begin{array}{c}0.002 \\
(0.009) \\
\end{array}$ & $\begin{array}{c}0.002 \\
(0.008) \\
\end{array}$ & $\begin{array}{c}0.008 \\
(0.008) \\
\end{array}$ & $\begin{array}{c}0.007 \\
(0.008)\end{array}$ \\
\hline State FE & & $\mathrm{X}$ & & $\mathrm{X}$ & & $\mathrm{X}$ & & $\mathrm{X}$ \\
\hline $\mathrm{N}$ & 756 & 756 & 785 & 785 & 773 & 773 & 768 & 768 \\
\hline $\mathrm{R}^{2}$ & 0.051 & 0.241 & 0.052 & 0.277 & 0.084 & 0.360 & 0.058 & 0.276 \\
\hline
\end{tabular}

Notes: As in Table 1 except that all regressions control for the 2016 values of (log) population, share Black, share White, share Hispanic, share high school dropouts, share high school graduates, unemployment rate, share out of labor force, share males ages $15-34 .{ }^{*} p<0.05,{ }^{* *} p<0.01,{ }^{* * *} p<0.001$. 
Table A4: The Effect of the Executive Order on Local Crime Rates: Continuous Differencein-Differences, Adding Controls

\begin{tabular}{|c|c|c|c|c|c|c|c|c|}
\hline & \multicolumn{4}{|c|}{ Crime Rates } & \multicolumn{4}{|c|}{ Log Number of Crimes } \\
\hline & (1) & $(2)$ & $(3)$ & $(4)$ & $(5)$ & $(6)$ & $(7)$ & $(8)$ \\
\hline & Property & Property & Violent & Violent & Property & Property & Violent & Violent \\
\hline Diff-in-Diff & $\begin{array}{c}-106.558 \\
(196.045)\end{array}$ & $\begin{array}{c}107.680 \\
(230.128)\end{array}$ & $\begin{array}{c}47.041 \\
(53.452)\end{array}$ & $\begin{array}{c}2.170 \\
(45.452)\end{array}$ & & & & \\
\hline Diff-in-Diff & & & & & $\begin{array}{c}0.010^{* *} \\
(0.003)\end{array}$ & $\begin{array}{c}0.004 \\
(0.006)\end{array}$ & $\begin{array}{l}-0.001 \\
(0.004)\end{array}$ & $\begin{array}{c}0.007 \\
(0.005)\end{array}$ \\
\hline County Trends & & $\mathrm{X}$ & & $\mathrm{X}$ & & $\mathrm{X}$ & & $\mathrm{X}$ \\
\hline $\mathrm{N}$ & 6232 & 6232 & 6232 & 6232 & 6232 & 6232 & 6232 & 6232 \\
\hline $\mathrm{R}^{2}$ & 0.915 & 0.954 & 0.941 & 0.969 & 0.977 & 0.987 & 0.977 & 0.986 \\
\hline $\bar{Y}$ & 2348.1 & 2348.1 & 305.0 & 305.0 & 8.0 & 8.0 & 5.8 & 5.8 \\
\hline $\operatorname{sd}(Y)$ & 1174.2 & 1174.2 & 242.6 & 242.6 & 1.6 & 1.6 & 1.7 & 1.7 \\
\hline
\end{tabular}

Notes: As in Table 2 except that all regressions control for the contemporaneous (log) population, share Black, share White, share Hispanic, share high school dropouts, share high school graduates, unemployment rate, share out of labor force, share males age $15-34 .{ }^{*} p<0.05,{ }^{* *} p<0.01,{ }^{* * *} p<0.001$. 


\subsubsection{Adding Spatial Spillovers in Crime as a Control}

- Previous studies have demonstrated the existence of crime-related spatial spillovers (see, e.g., Blattman et al. 2017). Therefore, we follow the procedure outlined in Bianchi et al. (2012) to control for spatial spillovers in crime.

- Specifically, for each county (and year) in our sample, we calculated a weighted average of all crime variables among the neighboring counties (in the same year) where the weights were the distances between the counties' centroids. We used this and this sources.

- We then ran our main specification with controlling for this spatial crime variable.

Table A5: The Effect of the Executive Order on Local Crime Rates: Controlling for Spatial Spillovers

\begin{tabular}{|c|c|c|c|c|c|c|c|c|}
\hline & \multicolumn{4}{|c|}{ Crime Rates } & \multicolumn{4}{|c|}{ Log Number of Crimes } \\
\hline & (1) & $(2)$ & $(3)$ & $(4)$ & $(5)$ & $(6)$ & $(7)$ & $(8)$ \\
\hline & Property & Property & Violent & Violent & Property & Property & Violent & Violent \\
\hline Diff-in-Diff & $\begin{array}{c}-430.251^{*} \\
(205.169)\end{array}$ & $\begin{array}{c}154.433 \\
(182.200)\end{array}$ & $\begin{array}{c}36.455 \\
(50.600)\end{array}$ & $\begin{array}{c}3.212 \\
(50.194)\end{array}$ & & & & \\
\hline Diff-in-Diff & & & & & $\begin{array}{c}0.010^{*} \\
(0.004)\end{array}$ & $\begin{array}{c}0.005 \\
(0.006)\end{array}$ & $\begin{array}{c}0.000 \\
(0.005)\end{array}$ & $\begin{array}{c}0.004 \\
(0.005)\end{array}$ \\
\hline County Trends & & $\mathrm{X}$ & & $\mathrm{X}$ & & $\mathrm{X}$ & & $\mathrm{X}$ \\
\hline $\mathrm{N}$ & 6795 & 6795 & 6795 & 6795 & 6795 & 6795 & 6795 & 6795 \\
\hline $\mathrm{R}^{2}$ & 0.920 & 0.956 & 0.940 & 0.967 & 0.974 & 0.984 & 0.975 & 0.985 \\
\hline $\bar{Y}$ & 2379.6 & 2379.6 & 303.3 & 303.3 & 7.9 & 7.9 & 5.7 & 5.7 \\
\hline $\operatorname{sd}(\mathrm{Y})$ & 1196.4 & 1196.4 & 243.5 & 243.5 & 1.6 & 1.6 & 1.7 & 1.7 \\
\hline
\end{tabular}

Notes: As in Table 2 except that we control for the spatial crime lag variable defined above. ${ }^{*} p<0.05$, ${ }^{* *} p<0.01,{ }^{* * *} p<0.001$. 


\subsubsection{Subset to Urban Counties}

- Heterogeneous crime responses to demographic changes may be relevant in the study's context, and a null effect may conceal differential effects within subgroups.

- Therefore, we replicate Table 2 on the subset of counties with above-median population density, to test for evidence of an effect in urban areas.

Table A6: The Effect of the Executive Order on Local Crime Rates: Urban Counties, 20102018

\begin{tabular}{|c|c|c|c|c|c|c|c|c|}
\hline & \multicolumn{4}{|c|}{ Crime Rates } & \multicolumn{4}{|c|}{ Log Number of Crimes } \\
\hline & $(1)$ & $(2)$ & $(3)$ & $(4)$ & $(5)$ & $(6)$ & $(7)$ & $(8)$ \\
\hline & Property & Property & Violent & Violent & Property & Property & Violent & Violent \\
\hline Diff-in-Diff & $\begin{array}{l}-290.405 \\
(252.426)\end{array}$ & $\begin{array}{c}177.183 \\
(231.958)\end{array}$ & $\begin{array}{c}27.595 \\
(54.302)\end{array}$ & $\begin{array}{l}-19.312 \\
(48.558)\end{array}$ & & & & \\
\hline Diff-in-Diff & & & & & $\begin{array}{c}0.013^{* * *} \\
(0.004)\end{array}$ & $\begin{array}{c}0.006 \\
(0.004)\end{array}$ & $\begin{array}{l}-0.000 \\
(0.004)\end{array}$ & $\begin{array}{c}0.000 \\
(0.004)\end{array}$ \\
\hline County Trends & & $\mathrm{X}$ & & $\mathrm{X}$ & & $\mathrm{X}$ & & $\mathrm{X}$ \\
\hline $\mathrm{N}$ & 3537 & 3537 & 3537 & 3537 & 3537 & 3537 & 3537 & 3537 \\
\hline $\mathrm{R}^{2}$ & 0.928 & 0.968 & 0.960 & 0.982 & 0.976 & 0.989 & 0.979 & 0.989 \\
\hline $\bar{Y}$ & 2624.1 & 2624.1 & 355.2 & 355.2 & 8.9 & 8.9 & 6.7 & 6.7 \\
\hline $\operatorname{sd}(\mathrm{Y})$ & 1237.3 & 1237.3 & 286.8 & 286.8 & 1.2 & 1.2 & 1.5 & 1.5 \\
\hline
\end{tabular}

Notes: As in Table 2 except we focus on our sample of counties with above median population density. ${ }^{*} p<0.05,{ }^{* *} p<0.01,{ }^{* * *} p<0.001$. 


\subsubsection{Use All US Counties}

- Replicating Table 2 with all US counties (regardless of whether they have had a resettled refugee since 2010).

- To accommodate the skewness of the right hand side variable (measure of exposure to the Executive Order) that is introduced by added a large number of counties that never receive refugees, we bin this variable into three groups: counties with no refugees ("No Refugees"), counties with below median number of refugees ("Low Refugees") and counties with above median number of refugees (the omitted group). The table presents the coefficients of the interactions of "No Refugees' and "Low Refugees" variables with year dummies indicating the post-Executive Order period. The hypothesis that refugees increase crime rates would be consistent with negative and statistically significant coefficients.

Table A7: The Effect of the Executive Order on Local Crime Rates: All US Counties, 2010-2018

\begin{tabular}{|c|c|c|c|c|c|c|c|c|}
\hline & \multicolumn{4}{|c|}{ Crime Rates } & \multicolumn{4}{|c|}{ Log Number of Crimes } \\
\hline & $(1)$ & $(2)$ & $(3)$ & $(4)$ & $(5)$ & $(6)$ & (7) & (8) \\
\hline & Property & Property & Violent & Violent & Property & Property & Violent & Violent \\
\hline No Refugees $\times$ Post & $\begin{array}{c}145.093^{* *} \\
(47.124)\end{array}$ & $\begin{array}{l}-42.441 \\
(47.805)\end{array}$ & $\begin{array}{c}2.983 \\
(10.162)\end{array}$ & $\begin{array}{l}-7.763 \\
(7.548)\end{array}$ & & & & \\
\hline Low Refugees $\times$ Post & $\begin{array}{c}9.747 \\
(42.396)\end{array}$ & $\begin{array}{l}-49.091 \\
(45.655)\end{array}$ & $\begin{array}{c}-16.446^{*} \\
(6.301)\end{array}$ & $\begin{array}{r}-12.306 \\
(7.874)\end{array}$ & & & & \\
\hline No Refugees $\times$ Post & & & & & $\begin{array}{c}-0.105^{*} \\
(0.041)\end{array}$ & $\begin{array}{l}-0.035 \\
(0.039)\end{array}$ & $\begin{array}{l}-0.026 \\
(0.036)\end{array}$ & $\begin{array}{l}-0.009 \\
(0.036)\end{array}$ \\
\hline Low Refugees $\times$ Post & & & & & $\begin{array}{l}-0.027 \\
(0.031)\end{array}$ & $\begin{array}{l}-0.014 \\
(0.044)\end{array}$ & $\begin{array}{l}-0.026 \\
(0.030)\end{array}$ & $\begin{array}{l}-0.001 \\
(0.045)\end{array}$ \\
\hline County Trends & & $\mathrm{X}$ & & $\mathrm{X}$ & & $\mathrm{X}$ & & $\mathrm{X}$ \\
\hline $\mathrm{N}$ & 27999 & 27999 & 27999 & 27999 & 27999 & 27999 & 27999 & 27999 \\
\hline $\mathrm{R}^{2}$ & 0.852 & 0.903 & 0.819 & 0.889 & 0.953 & 0.974 & 0.951 & 0.969 \\
\hline $\bar{Y}$ & 1794.2 & 1794.2 & 241.7 & 241.7 & 5.9 & 5.9 & 3.9 & 3.9 \\
\hline $\operatorname{sd}(Y)$ & 1210.5 & 1210.5 & 241.8 & 241.8 & 2.1 & 2.1 & 2.0 & 2.0 \\
\hline
\end{tabular}

Notes: As in Table 2 except we include all US counties. ${ }^{*} p<0.05,{ }^{* *} p<0.01,{ }^{* * *} p<0.001$. 


\subsubsection{Weighted Regressions}

- Replicating Tables 1 and 2 with weighting each regression by the 2016 population.

Table A8: The Effect of the Executive Order on Local Crime Rates: First Differences, Weighted Regressions

\begin{tabular}{|c|c|c|c|c|c|c|c|c|}
\hline & \multicolumn{4}{|c|}{ Crime Rates } & \multicolumn{4}{|c|}{ Log Number of Crimes } \\
\hline & $(1)$ & $(2)$ & $(3)$ & $(4)$ & $(5)$ & $(6)$ & $(7)$ & $(8)$ \\
\hline & Property & Property & Violent & Violent & Property & Property & Violent & Violent \\
\hline$\Delta$ refugees per capita ${ }^{\text {pre-post }}$ & $\begin{array}{c}163.257 \\
(203.336)\end{array}$ & $\begin{array}{c}283.024 \\
(184.369)\end{array}$ & $\begin{array}{l}-74.545 \\
(81.744)\end{array}$ & $\begin{array}{l}-20.501 \\
(80.986)\end{array}$ & & & & \\
\hline$\Delta \log (\text { refugees })^{\text {pre-post }}$ & & & & & $\begin{array}{l}-0.007 \\
(0.010)\end{array}$ & $\begin{array}{c}-0.012 \\
(0.009)\end{array}$ & $\begin{array}{c}0.004 \\
(0.011)\end{array}$ & $\begin{array}{l}-0.001 \\
(0.009)\end{array}$ \\
\hline State FE & & $\mathrm{X}$ & & $\mathrm{X}$ & & $\mathrm{X}$ & & $\mathrm{X}$ \\
\hline $\mathrm{N}$ & 756 & 756 & 785 & 785 & 773 & 773 & 768 & 768 \\
\hline $\mathrm{R}^{2}$ & 0.001 & 0.235 & 0.002 & 0.277 & 0.001 & 0.341 & 0.000 & 0.286 \\
\hline
\end{tabular}

Notes: As in Table 1 except that all regressions are weighted by the 2016 population. ${ }^{*} p<0.05$, ${ }^{* *} p<0.01,{ }^{* * *} p<0.001$.

Table A9: The Effect of the Executive Order on Local Crime Rates: Continuous Differencein-Differences, Weighted Regressions

\begin{tabular}{|c|c|c|c|c|c|c|c|c|}
\hline & \multicolumn{4}{|c|}{ Crime Rates } & \multicolumn{4}{|c|}{ Log Number of Crimes } \\
\hline & $(1)$ & $(2)$ & $(3)$ & $(4)$ & $(5)$ & $(6)$ & $(7)$ & $(8)$ \\
\hline & Property & Property & Violent & Violent & Property & Property & Violent & Violent \\
\hline Diff-in-Diff & $\begin{array}{l}-207.877 \\
(228.400)\end{array}$ & $\begin{array}{c}224.315 \\
(222.888)\end{array}$ & $\begin{array}{c}62.945 \\
(60.163)\end{array}$ & $\begin{array}{c}13.150 \\
(51.434)\end{array}$ & & & & \\
\hline Diff-in-Diff & & & & & $\begin{array}{c}0.014^{* * *} \\
(0.003)\end{array}$ & $\begin{array}{c}0.006 \\
(0.005)\end{array}$ & $\begin{array}{c}0.001 \\
(0.005)\end{array}$ & $\begin{array}{c}0.005 \\
(0.004)\end{array}$ \\
\hline County Trends & & $\mathrm{X}$ & & $\mathrm{X}$ & & $\mathrm{X}$ & & $\mathrm{X}$ \\
\hline $\mathrm{N}$ & 7065 & 7065 & 7065 & 7065 & 7065 & 7065 & 7065 & 7065 \\
\hline $\mathrm{R}^{2}$ & 0.912 & 0.954 & 0.941 & 0.969 & 0.975 & 0.985 & 0.977 & 0.986 \\
\hline $\bar{Y}$ & 2422.8 & 2422.8 & 315.2 & 315.2 & 8.1 & 8.1 & 5.9 & 5.9 \\
\hline $\operatorname{sd}(\mathrm{Y})$ & 1197.9 & 1197.9 & 251.7 & 251.7 & 1.6 & 1.6 & 1.7 & 1.7 \\
\hline
\end{tabular}

Notes: As in Table 2 except that all regressions are weighted by the 2016 population. ${ }^{*} p<0.05$, ${ }^{* *} p<0.01,{ }^{* * *} p<0.001$. 


\subsubsection{First-Differences Model without Dropping Outliers}

- Replicating Table 1 without dropping counties with changes in crime rates larger than 1000 in absolute value.

Table A10: The Effect of the Executive Order on Local Crime Rates: First Differences, All Sample Counties

\begin{tabular}{|c|c|c|c|c|c|c|c|c|}
\hline & \multicolumn{4}{|c|}{ Crime Rates } & \multicolumn{4}{|c|}{ Log Number of Crimes } \\
\hline & $(1)$ & $(2)$ & $(3)$ & (4) & $(5)$ & $(6)$ & $(7)$ & $(8)$ \\
\hline & Property & Property & Violent & Violent & Property & Property & Violent & Violent \\
\hline$\Delta$ refugees per capita $^{\text {pre-post }}$ & $\begin{array}{c}1.251 \\
(281.267)\end{array}$ & $\begin{array}{c}266.795 \\
(266.056)\end{array}$ & $\begin{array}{l}-59.126 \\
(81.784)\end{array}$ & $\begin{array}{l}-12.788 \\
(82.462)\end{array}$ & & & & \\
\hline$\Delta \log (\text { refugees })^{\text {pre-post }}$ & & & & & $\begin{array}{l}-0.003 \\
(0.017) \\
\end{array}$ & $\begin{array}{l}-0.002 \\
(0.019) \\
\end{array}$ & $\begin{array}{l}-0.004 \\
(0.016)\end{array}$ & $\begin{array}{c}-0.003 \\
(0.016) \\
\end{array}$ \\
\hline State FE & & $\mathrm{X}$ & & $\mathrm{X}$ & & $\mathrm{X}$ & & $\mathrm{X}$ \\
\hline $\mathrm{N}$ & 785 & 785 & 785 & 785 & 785 & 785 & 785 & 785 \\
\hline $\mathrm{R}^{2}$ & 0.000 & 0.225 & 0.001 & 0.253 & 0.000 & 0.100 & 0.000 & 0.174 \\
\hline
\end{tabular}

Notes: As in Table 1 except that we do not drop any observations. ${ }^{*} p<0.05,{ }^{* *} p<0.01,{ }^{* * *} p<0.001$. 


\subsubsection{Common Support Assumption}

- As discussed in the Appendix section titled, "Identifying Assumptions in a Difference-indifferences Design," covariates in empirical models should have common support across treatment levels. The only covariates in our main specification are state and year fixed effects. By design, year fixed effects are balanced between the "treatment" and "control" counties. However, it is not clear that this is true for the state fixed effects.

- To test for common support among the state dummies, we separated all counties in our sample into 2 bins depending on the value of our treatment variable (in the rate specification, number of refugees in 2016 per 100 capita) - above ("treatment") and below ("control") the median value.

- We then checked whether each state has counties in both bins. This was true for all states except for Delaware (contained counties only in the "control" group), Hawaii (only in "control"), Nevada (only in "treatment") and Wyoming (only in "treatment").

- Lastly, we ran our main specification when dropping these four states from the sample.

Table A11: The Effect of the Executive Order on Local Crime Rates: Dropping States Without Common Support

\begin{tabular}{|c|c|c|c|c|c|c|c|c|}
\hline & \multicolumn{4}{|c|}{ Crime Rates } & \multicolumn{4}{|c|}{ Log Number of Crimes } \\
\hline & (1) & (2) & (3) & (4) & $(5)$ & (6) & $(7)$ & $(8)$ \\
\hline & Property & Property & Violent & Violent & Property & Property & Violent & Violent \\
\hline Diff-in-Diff & $\begin{array}{l}-200.757 \\
(208.427)\end{array}$ & $\begin{array}{c}207.272 \\
(208.413)\end{array}$ & $\begin{array}{c}51.031 \\
(57.370)\end{array}$ & $\begin{array}{c}3.417 \\
(51.447)\end{array}$ & & & & \\
\hline Diff-in-Diff & & & & & $\begin{array}{c}0.013^{* *} \\
(0.004)\end{array}$ & $\begin{array}{c}0.006 \\
(0.006)\end{array}$ & $\begin{array}{c}0.001 \\
(0.005) \\
\end{array}$ & $\begin{array}{c}0.006 \\
(0.005)\end{array}$ \\
\hline County Trends & & $\mathrm{X}$ & & $\mathrm{X}$ & & $\mathrm{X}$ & & $\mathrm{X}$ \\
\hline $\mathrm{N}$ & 6993 & 6993 & 6993 & 6993 & 6993 & 6993 & 6993 & 6993 \\
\hline $\mathrm{R}^{2}$ & 0.911 & 0.953 & 0.936 & 0.965 & 0.974 & 0.984 & 0.975 & 0.985 \\
\hline $\bar{Y}$ & 2377.7 & 2377.7 & 305.1 & 305.1 & 7.9 & 7.9 & 5.8 & 5.8 \\
\hline $\operatorname{sd}(Y)$ & 1194.7 & 1194.7 & 243.4 & 243.4 & 1.6 & 1.6 & 1.7 & 1.7 \\
\hline
\end{tabular}

Notes: As in Table 2 except that the states Delaware, Hawaii, Nevada and Wyoming were dropped from the sample. ${ }^{*} p<0.05,{ }^{* *} p<0.01,{ }^{* * *} p<0.001$. 


\subsection{Alternative Outcome Variables}

\subsubsection{Testing for Effects on One-Year Lead Crime Rates}

- Crime may take more than a year to manifest an effect from a demographic shock.

- Therefore, we replicate Table 2 with a one-year lead crime as the outcome.

Table A12: The Effect of the Executive Order on Local Crime Rates: Continuous Differencein-Differences, One-year Lead Crime as Outcome

\begin{tabular}{|c|c|c|c|c|c|c|c|c|}
\hline & \multicolumn{4}{|c|}{ Crime Rates } & \multicolumn{4}{|c|}{ Log Number of Crimes } \\
\hline & (1) & $(2)$ & $(3)$ & $(4)$ & $(5)$ & $(6)$ & $(7)$ & $(8)$ \\
\hline & Property & Property & Violent & Violent & Property & Property & Violent & Violent \\
\hline Diff-in-Diff & $\begin{array}{c}-67.957 \\
(211.274)\end{array}$ & $\begin{array}{c}135.274 \\
(186.552)\end{array}$ & $\begin{array}{c}38.749 \\
(48.972)\end{array}$ & $\begin{array}{l}-19.157 \\
(32.025)\end{array}$ & & & & \\
\hline Diff-in-Diff & & & & & $\begin{array}{c}0.016^{* * *} \\
(0.004)\end{array}$ & $\begin{array}{c}0.007 \\
(0.004)\end{array}$ & $\begin{array}{c}0.002 \\
(0.005)\end{array}$ & $\begin{array}{c}0.005 \\
(0.004)\end{array}$ \\
\hline County Trends & & $\mathrm{X}$ & & $\mathrm{X}$ & & $\mathrm{X}$ & & $\mathrm{X}$ \\
\hline $\mathrm{N}$ & 6280 & 6280 & 6280 & 6280 & 6280 & 6280 & 6280 & 6280 \\
\hline $\mathrm{R}^{2}$ & 0.913 & 0.953 & 0.940 & 0.968 & 0.976 & 0.985 & 0.976 & 0.985 \\
\hline $\bar{Y}$ & 2341.1 & 2341.1 & 303.9 & 303.9 & 7.9 & 7.9 & 5.8 & 5.8 \\
\hline $\operatorname{sd}(Y)$ & 1176.4 & 1176.4 & 242.3 & 242.3 & 1.6 & 1.6 & 1.7 & 1.7 \\
\hline
\end{tabular}

Notes: As in Table 2 except that we use one-year lead crime as the outcome variables. ${ }^{*} p<0.05$, ${ }^{* *} p<0.01,{ }^{* * *} p<0.001$. 


\subsubsection{Share In-Movers}

- A potential concern is that natives or other foreigners might migrate internally as a response to lower refugee arrivals induced by the Executive Order. This might bias our results if the internal migration somehow affects crime rates.

- To test for this, we ran our regression models with the outcome variable being the number of people who were in a "different house in US 1 year ago in a different MSA" per 100,000 people and the log number of people who were in a "different house in US 1 year ago in a different MSA". Data come from Manson et al. (2020).

Table A13: The Executive Order and Internal In-migration: First Differences

\begin{tabular}{|c|c|c|c|c|}
\hline & \multicolumn{2}{|c|}{ Rates } & \multicolumn{2}{|c|}{$\log$} \\
\hline & $\Delta$ Share In-movers & $\Delta$ Share In-movers & $\% \Delta \stackrel{(3)}{\%}$ & $\% \Delta$ In-movers \\
\hline$\Delta$ refugees per capita ${ }^{\text {pre-post }}$ & $\begin{array}{c}73.320 \\
(578.927)\end{array}$ & $\begin{array}{c}186.099 \\
(568.016)\end{array}$ & & \\
\hline$\Delta \log (\text { refugees })^{\text {pre-post }}$ & & & $\begin{array}{l}-0.002 \\
(0.006)\end{array}$ & $\begin{array}{l}-0.000 \\
(0.007)\end{array}$ \\
\hline $\begin{array}{l}\text { State FE } \\
\mathrm{N}\end{array}$ & 785 & $\underset{785}{\mathrm{X}}$ & 785 & $\underset{785}{X}$ \\
\hline $\mathrm{R}^{2}$ & 0.000 & 0.083 & 0.000 & 0.219 \\
\hline
\end{tabular}

Notes: As in Table 1 except that the outcome variable is the pre-post change in the number of people who were in a "different house in US 1 year ago in a different MSA" per 100,000 population (columns 1-2) and the change in the log number of people who were in a "different house in US 1 year ago in a different MSA" (columns $3-4) .{ }^{*} p<0.05,{ }^{* *} p<0.01,{ }^{* * *} p<0.001$.

Table A14: The Executive Order and Internal In-migration: Continuous Difference-inDifferences

\begin{tabular}{|c|c|c|c|c|}
\hline & \multicolumn{2}{|c|}{ Rates } & \multicolumn{2}{|c|}{ Logs } \\
\hline & $\begin{array}{c}(1) \\
\text { Share In-movers }\end{array}$ & $\begin{array}{c}(2) \\
\text { Share In-movers }\end{array}$ & $\begin{array}{c}(3) \\
\text { Log \# In-movers }\end{array}$ & Log \# In-movers \\
\hline Diff-in-Diff & $\begin{array}{l}-135.916 \\
(392.789)\end{array}$ & $\begin{array}{l}-417.353 \\
(364.075)\end{array}$ & & \\
\hline Diff-in-Diff & & & $\begin{array}{c}-0.013 \\
(0.008)\end{array}$ & $\begin{array}{l}0.021^{*} \\
(0.008)\end{array}$ \\
\hline County Trends & & $\mathrm{X}$ & & $\mathrm{X}$ \\
\hline $\mathrm{N}$ & 7065 & 7065 & 7065 & 7065 \\
\hline $\mathrm{R}^{2}$ & 0.951 & 0.983 & 0.968 & 0.989 \\
\hline $\bar{Y}$ & 2830.1 & 2830.1 & 6.6 & 6.6 \\
\hline $\operatorname{sd}(Y)$ & 2448.6 & 2448.6 & 4.0 & 4.0 \\
\hline
\end{tabular}

Notes: As in Table 2 except that the outcome variable is the number of people who were in a "different house in US 1 year ago in a different MSA" per 100,000 population (columns 1-2) and the log number of people who were in a "different house in US 1 year ago in a different MSA" (columns 3-4). * $p<0.05$, ${ }^{* *} p<0.01,{ }^{* * *} p<0.001$. 


\subsubsection{Police Behavior and Crime Reporting}

- A potential concern is that the change in refugee resettlement induced by the Executive Order might be correlated with changes in police behavior or effort. For instance, it might be that the documented number of crimes remains unchanged while the actual number of committed crimes increases (or decreases).

- We conducted two tests which might address this concern. First, we ran regressions in which the outcome was the number of "total offenses cleared by arrest or exceptional means divided by the number of actual offenses." Data come from Manson et al. (2020).

Table A15: The Executive Order and the Share of Cleared Crimes: First Differences

\begin{tabular}{|c|c|c|c|c|}
\hline & \multicolumn{2}{|c|}{ Rates } & \multicolumn{2}{|c|}{$\log$} \\
\hline & $\begin{array}{c}(1) \\
\text { Share } \\
\text { Cleared Property }\end{array}$ & $\begin{array}{c}(2) \\
\text { Share } \\
\text { Cleared Property }\end{array}$ & $\begin{array}{c}(3) \\
\text { Share } \\
\text { Cleared Violent }\end{array}$ & $\begin{array}{c}(4) \\
\text { Share } \\
\text { Cleared Violent }\end{array}$ \\
\hline$\Delta$ refugees per capita ${ }^{\text {pre-post }}$ & $\begin{array}{c}-0.028 \\
(0.068)\end{array}$ & $\begin{array}{l}-0.006 \\
(0.051)\end{array}$ & & \\
\hline$\Delta \log (\text { refugees })^{\text {pre-post }}$ & & & $\begin{array}{l}-0.003 \\
(0.003)\end{array}$ & $\begin{array}{l}-0.004 \\
(0.004)\end{array}$ \\
\hline State FE & & $\mathrm{X}$ & & $\mathrm{X}$ \\
\hline $\mathrm{N}$ & 785 & 785 & 782 & 782 \\
\hline $\mathrm{R}^{2}$ & 0.000 & 0.030 & 0.001 & 0.106 \\
\hline
\end{tabular}

Notes: As in Table 1 except that the outcome variable is the share of "total offenses cleared by an arrest or exceptional means". ${ }^{*} p<0.05,{ }^{* *} p<0.01,{ }^{* * *} p<0.001$.

Table A16: The Executive Order and the Share of Cleared Crimes: Continuous Differencein-Differences

\begin{tabular}{lcccccccc}
\hline \hline & $(1)$ & $(2)$ & $(3)$ & $(4)$ & $(5)$ & $(6)$ & $(7)$ & $(8)$ \\
& Property & Property & Violent & Violent & $\begin{array}{c}(8) \\
\text { Property }\end{array}$ & $\begin{array}{c}\text { Property } \\
\text { Violent }\end{array}$ & Violent \\
\hline Diff-in-Diff & -0.023 & 0.039 & 0.040 & 0.030 & & & & \\
& $(0.031)$ & $(0.059)$ & $(0.036)$ & $(0.031)$ & & & & \\
Diff-in-Diff & & & & & & & & \\
& & & & & -0.001 & 0.003 & 0.000 & 0.002 \\
& & & & & $(0.002)$ & $(0.004)$ & $(0.001)$ & $(0.002)$ \\
\hline County Trends & & $\mathrm{X}$ & & $\mathrm{X}$ & & $\mathrm{X}$ & & $\mathrm{X}$ \\
$\mathrm{N}$ & 7051 & 7051 & 7027 & 7027 & 7051 & 7051 & 7027 & 7027 \\
$\mathrm{R}^{2}$ & 0.182 & 0.206 & 0.754 & 0.813 & 0.182 & 0.206 & 0.754 & 0.813 \\
$\bar{Y}$ & 0.2 & 0.2 & 0.5 & 0.5 & 0.2 & 0.2 & 0.5 & 0.5 \\
$\operatorname{sd}(\mathrm{Y})$ & 0.3 & 0.3 & 0.2 & 0.2 & 0.3 & 0.3 & 0.2 & 0.2 \\
\hline \hline
\end{tabular}

Notes: As in Table 2 except that the outcome variable is the share of "total offenses cleared by an arrest or exceptional means". ${ }^{*} p<0.05,{ }^{* *} p<0.01,{ }^{* * *} p<0.001$. 
- Second, we ran regressions in which the outcome variable was the share of male law enforcement agents. Data come from Manson et al. (2020).

Table A17: The Executive Order and the Share of Male Law Enforcement Agents: First Differences

\begin{tabular}{|c|c|c|c|c|}
\hline & \multicolumn{2}{|c|}{ Rates } & \multicolumn{2}{|c|}{$\log$} \\
\hline & $(1)$ & $(2)$ & $(3)$ & $(4)$ \\
\hline & Share Male Police & Share Male Police & Share Male Police & Share Male Police \\
\hline$\Delta$ refugees per capita ${ }^{\text {pre-post }}$ & $\begin{array}{l}-0.198 \\
(0.150)\end{array}$ & $\begin{array}{l}-0.221 \\
(0.159)\end{array}$ & & \\
\hline$\Delta \log (\text { refugees })^{\text {pre-post }}$ & & & $\begin{array}{l}-0.000 \\
(0.002)\end{array}$ & $\begin{array}{c}0.002 \\
(0.003)\end{array}$ \\
\hline State FE & & $\mathrm{X}$ & & $\mathrm{X}$ \\
\hline $\mathrm{N}$ & 785 & 785 & 785 & 785 \\
\hline $\mathrm{R}^{2}$ & 0.014 & 0.084 & 0.000 & 0.069 \\
\hline
\end{tabular}

Notes: As in Table 1 except that the outcome variable is the pre-post change in the share of men among all employees in "protective service occupations: law enforcement." ${ }^{*} p<0.05,{ }^{* *} p<0.01,{ }^{* * *} p<0.001$.

Table A18: The Executive Order and the Share of Male Law Enforcement Agents: Continuous Difference-in-Differences

\begin{tabular}{|c|c|c|c|c|}
\hline & \multicolumn{2}{|c|}{ Rates } & \multicolumn{2}{|c|}{ Logs } \\
\hline & $(1)$ & $(2)$ & $(3)$ & $(4)$ \\
\hline & Share Male Police & Share Male Police & Share Male Police & Share Male Police \\
\hline \multirow[t]{2}{*}{ Diff-in-Diff } & $0.174^{*}$ & 0.162 & & \\
\hline & $(0.066)$ & $(0.124)$ & & \\
\hline \multirow[t]{2}{*}{ Diff-in-Diff } & & & 0.001 & 0.000 \\
\hline & & & $(0.001)$ & $(0.002)$ \\
\hline County Trends & & $\mathrm{X}$ & & $\mathrm{X}$ \\
\hline $\mathrm{N}$ & 7062 & 7062 & 7062 & 7062 \\
\hline $\mathrm{R}^{2}$ & 0.552 & 0.771 & 0.550 & 0.770 \\
\hline $\bar{Y}$ & 0.8 & 0.8 & 0.8 & 0.8 \\
\hline $\operatorname{sd}(Y)$ & 0.1 & 0.1 & 0.1 & 0.1 \\
\hline
\end{tabular}

Notes: As in Table 2 except that the outcome variable is the share of men among all employees in "protective service occupations: law enforcement." ${ }^{*} p<0.05,{ }^{* *} p<0.01,{ }^{* * *} p<0.001$. 


\subsection{Secondary migration}

- To estimate the magnitude of secondary refugee migration to a different state after arrival, we use ORR data. For reasons of data protection, ORR only publishes aggregate (state-level) statistics on secondary in- and out-migration.

- Ideally, we would use data from 2017 and 2018 but it is not available. The closest time period we found was 2013 and 2014. The only other source of refugee secondary migration we identified were averages from 2000-2014 (Mossaad et al., 2020). Because inter-state migration among the general population has been trending downward since 2000 (Molloy et al., 2011), we sought more recent estimates of migration.

- We use data from the US Office of Refugee Resettlement's (ORR) annual reports to calculate the number of refugees who made inter-state moves in 2013 and 2014 (U.S. Department of Health and Human Services: Office of Refugee Resettlement, 2014, 2015). We estimate that approximately $3.9 \%$ of refugees who had arrived in the past four years moved per year.

- We use this four-year time window since after that period, resettled refugees can apply for naturalization.

- ORR publishes how many refugees (including those formally resettled to the US and Cuban and Haitian refugees, which constitute a different program) pre-naturalization moved to a different state each year.

- For each year, 2013 and 2014, we divide the number of movers by the total number of refugees resettled (and Cuban and Haitian refugee arrivals) in the previous 4 years (2010-2013 and 2011-2014, respectively).

- Since the data on arrivals and movers for 2013 (and 2014) include both new arrivals in that year and people who had previously arrived and moved in that year, we estimate inter-state moving rates for each year with and without new arrivals from the year. This produces upper and lower bounds, respectively, for the estimates.

- We take the mean of those two estimates for 2013 and 2014 to calculate our final inter-state moving estimate, $3.9 \%$. 


\subsection{Precision}

- To gauge the precision of our estimates of the impact of halting refugee resettlement on crime, we begin by calculate the change in crime following a one standard deviation (or a one percent) increase in refugee resettlement as predicted by our statistical models presented in the odd-numbered columns in Tables 1 and 2.

- In order to interpret the magnitude of the predicted changes in Columns 1 and 2, we present the median crime rates above in the same columns.

- For the log specification, we present estimates in percent changes for a 1 percent increase in resettlement in Columns 3 and 4.

Table A19: Statistical Precision of the Estimated Impact of Refugee Resettlement on Crime

\begin{tabular}{|c|c|c|c|c|}
\hline \multirow{6}{*}{ Median Value } & \multicolumn{2}{|c|}{ Crime Rates } & \multicolumn{2}{|c|}{ Log Number of Crimes } \\
\hline & $(1)$ & $(2)$ & $(3)$ & $(4)$ \\
\hline & Property & Violent & Property & Violent \\
\hline & \multicolumn{4}{|c|}{ Panel A: Median Crime Values, 2010-2016 } \\
\hline & 2317.855 & 254.387 & - & - \\
\hline & $(19.366)$ & $(3.274)$ & - & - \\
\hline & \multicolumn{4}{|c|}{ Panel B: $\Delta$ Crime for a Given Increase in Resettlement } \\
\hline & \multicolumn{2}{|c|}{$1 \mathrm{SD}$ Increase } & \multicolumn{2}{|c|}{$1 \%$ Increase } \\
\hline First-Differences & 12.425 & -4.275 & $-0.007 \%$ & $0.003 \%$ \\
\hline Model & {$[-14.585,39.435]$} & {$[-16.151,7.602]$} & {$[-0.026 \%, 0.013 \%]$} & {$[-0.019 \%, 0.025 \%]$} \\
\hline Continuous & 14.597 & -3.696 & $-0.014 \%$ & $-0.001 \%$ \\
\hline Diff-in-Diff Model & {$[-15.544,44.738]$} & {$[-12.000,4.608]$} & {$[-0.021 \%,-0.006 \%]$} & {$[-0.011 \%, 0.009 \%]$} \\
\hline
\end{tabular}

Notes: Panel A shows the median crime values for number of crimes per 100,000 people (columns 1-2) and $\log$ absolute number of crimes (columns 3-4) in the pre-Executive Order period, 2010-2016. Standard errors are estimated via quantile (median) regression and shown in parenthesis. Panel B presents the estimated change in crime following a one standard deviation (columns 1-2) or a one percentage point (columns 3-4) increase in refugee resettlement predicted by our first-differences model (Table 2, odd-numbered columns) and our continuous difference-in-differences model (Table 3, odd-numbered columns). 95\% confidence intervals are shown in brackets. Values in columns 3 and 4 in Panel B are presented in percent, not log points. 


\section{Appendix References}

Blattman, Christopher, Donald Green, Daniel Ortega, and Santiago Tobón. "Pushing crime around the corner? Estimating experimental impacts of large-scale security interventions." Washington, DC: National Bureau of Economic Research, 2017.

Bianchi, Milo , Paolo Buonanno, and Paolo Pinotti, "Do immigrants cause crime?" Journal of the European Economic Association 10(6), 1318-1347, 2012.

Lechner, Michael, The Estimation of Causal Effects by Difference-in-Difference Methods. Now, 2011.

Manson, Steven, Jonathan Schroeder, David Van Riper, Tracy Kugler, and Steven Ruggles, "IPUMS National Historical Geographic Information System: Version 15.0 [dataset]," 2020 .

Molloy, Raven, Christopher L Smith, and Abigail Wozniak, "Internal migration in the United States." Journal of Economic Perspectives 25(3), 173-196, 2011.

Mossaad, Nadwa, Jeremy Ferwerda, Duncan Lawrence, Jeremy M Weinstein, and Jens Hainmueller, "Determinants of refugee naturalization in the United States." Proceedings of the National Academy of Sciences 115(37), 9175-9180, 2018.

U.S. Department of Health and Human Services: Office of Refugee Resettlement, "Statistical Abstract for Refugee Resettlement Stakeholders: July 2014." 2014.

-, "ORR Indicators for Refugee Resettlement Stakeholders: June 2015.” 2015. 